e. 


\section{GOD FOR US?}

An analysis and assessment of Dutch Reformed preaching during the apartheid years

\section{JOHAN CILLIERS}


God for us?

Published by SUN PReSS, a division of AFRICAN SUN MeDIA, Stellenbosch 7600 www.africansunmedia.co.za

www.sun-e-shop.co.za

All rights reserved.

Copyright (c) 2006 Johan Cilliers

No part of this book may be reproduced or transmitted in any form or by any electronic, photographic or mechanical means, including photocopying and recording on record, tape or laser disk, on microfilm, via the Internet, by e-mail, or by any other information storage and retrieval system, without prior written permission by the publisher.

First edition 2006

ISBN: 978-1-920109-12-7

e-ISBN: 978-1-920109-13-4

DOI: $10.18820 / 9781920109134$

Cover design by Soretha Botha

Typesetting by SUN MeDIA Stellenbosch

Set in 10/12 Warnock Pro

SUN PReSS is a division of AFRICAN SUN MeDIA, Stellenbosch University's publishing division. SUN PReSS publishes academic, professional and reference works in print and electronic format. This publication may be ordered directly from www.sun-e-shop.co.za 


\section{CONTENTS}

PREFACE 1 (1994)

i



CHAPTER 1

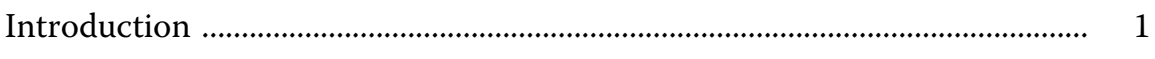

\section{CHAPTER 2}

The first hermeneutical step: backwards into, and out of, history

\section{CHAPTER 3}

The second hermeneutical step: inwards, into the potential of the "people's" soul

CHAPTER 4

The third hermeneutical step: outwards, with the projection of guilt 63

CHAPTER 5

Conclusion 


\section{PRefaCe 1 (1994)}

The great Reformer, Martin Luther, said that preaching is about the cor ecclesiae, the heart of the church - thus, about the heart of preaching, about the heart of the life of faith, as well as that of the congregation. Because, Luther says, preaching is about the heart of the Gospel: the message of salvation, of the justification of sinners. Preaching lives by this, the church lives by this, and Luther also lives by this.

Preaching touches the heart of the church, because it concerns the heart of Scripture, yes, the very heart of God. Preaching listens to God's voice (Calvin), where it hears the language of love, of God's compassion with a world in need. Preaching follows in God's footsteps (Luther), it follows the movement of his love in Jesus Christ and the movement of his care in the Holy Spirit. Preaching gives an insight into God's heart.

Preaching also provides an insight into the preacher's theology - above all, however, into the preacher's heart, into his/her loyalties, preferences and motives.... In preaching, the most profound secrets of the preacher's heart are revealed (cf. Lk 2:35), of his or her insight into the Word, into the Gospel, into the heart of God. "The heart is deceitful above all things..." (Jer 17:9) - also a minister's heart. Preaching reveals ministers' hearts, also their pretences, illusions and deceit. After all, ministers speak much about the Gospel, even much about God.... But: what type of Gospel, what type of God? A man-made God, a God made in the image and resemblance of the preacher. How true, how appallingly true!

This unnerves anyone who preaches, especially after one has read this moving and heart-rending work of Johan Cilliers: the result of an in-depth analysis of the under-ground, the ideological foundation - one could say the heart - of a number of sermons that were published in Die Kerkbode. ${ }^{1}$ They were heart-rending, as these sermons were published for all to read. Heart-rending, when one considers the opinion-making influence of all sermons, also how such sermons have

1 The official mouthpiece of the Dutch Reformed Church in South Africa. 
legitimized and perpetuated attitudes, values and actions.... Heart-rending, when one reads what such sermons about God have done with the Gospel, with God's heart, yes, with God Himself. Sermons that affected the church's heart, wounded it, hurt it ....

One is grateful that Johan Cilliers, together with an internationally renowned research team in Germany, introduced sermon analysis as a new homiletical genre to the South African research community. In the light of history, amongst other things, we must learn to preach, learn how we preached, what we must still learn and what we must unlearn. Through such empirical and rhetorical analysis, this research must continue, and also monitor the preaching in a new dispensation.

One is especially grateful that the author did not write only from his head, but especially from his heart. That, through this, he has addressed all preachers, yes also himself - called them to grieve profoundly over such sermons. To guide the church as ministers. To lead the church. I want to start with myself. I was also a minister when these sermons were preached. I heard such sermons. Perhaps, through the grace of God, I did not preach quite like that. But I want to confess that, on hearing such sermons, I did not protest loudly, did not protest against the wounding of the heart of the church, the heart of preaching, the heart of God. "What a wretched man I am!" (Rom 7:24). Mea culpa, mea maxima culpa!

This reminds me of Martin Niemöller's 1947 confession in Treysa: "We became tired of protesting when we feared humans more than the living God. Therefore, the catastrophe broke loose over all of us and dragged us along in its rapid pace. But we, the church, must beat our breasts and confess: I am guilty; it is my guilt, my enormous guilt."

PROF. BETHEL MÜLLER

Stellenbosch 1994 


\section{PReFACE 2 (2005)}

South Africa has entered the second decade of its first experience of democracy. Now South Africans have a further opportunity to look at each other over the demolished dividing walls of apartheid and, daily, to learn new aspects about each other. In the shining eyes of many there are signs of being amazed by each other, but also a shadow of concern about our future lives together. But deep in our hearts we embrace the promise of a better tomorrow for all.

Yet we know that no person can remember the promises for tomorrow without the capacity to recall the realities of yesterday. You cannot remember and cherish these promises, if you wish to forget the roots of the past from which these promises germinated.

This book by Johan Cilliers is one of the writings that help us to call into remembrance, and in doing so, to once again grieve for change. Here we see what disgraceful views about God and the volk (the people) formed the religioideological substructure of dominant sermons that were published in the official mouthpiece of the Dutch Reformed Church (DRC) during the period 1960 to 1980. It is important to be reminded of this, before we all acquire new ideological tricks. It will be to our collective benefit, in South Africa as well as abroad, if we learn from these analyses that our dream of unity in the church and nation must be uprooted from this ecclesiastical guilt, and that a new implantation is essential for the growth of the tree of God's promises for South Africa.

The title of this book identifies the core question: God for us? The question mark plays an important role in this book.

The only true stumbling block for church unity in the DRC family is the continuous existence of this question mark between the DRC and the Uniting Reformed Church. Here lies the great challenge of the second decade of democracy for these churches. The present crisis is best represented in the socalled Belhar debate. The misunderstanding of the pro-nobis principle (God for us) is the heart of the separation of Christians in this family of churches. The 
roots of this phenomenon, this misunderstanding, have never been better embodied than in this book by Johan Cilliers. Here the analysis of the sermons testifies to the actual historical reason why the DRC cannot accept the Belhar Confession. Ultimately, everything hinges on our view concerning the question: God for us? The hermeneutics of Belhar are in stark contrast to the hermeneutics revealed in this research done by Johan Cilliers. Belhar maintains that the "us" in this "God-for-us" principle must not be equated with the volk, the local congregation, the denomination or view of the majority. The "we" that God wishes to create is the "we" together with the "others." However, the others are not others by our own choice. They are the suffering, the marginalized and excluded others.

Hopefully, this book will help its readers to understand that God does not choose like human beings do. He goes further by calling every believer to participate in this strange way of choosing, contra human inclinations. Choose against yourself; that is, choose like God does. His question is never: "What is in it for me?" No, God's "for you" is for you, as the other person, an improbable, marginalized person, but also one who has tasted God's grace. Our national economic condition (the poor), the gender opportunities (for women), issues of sexual orientation and separation of classes confront us with this divine choice. Naturally, we make these kinds of choices privately and in our non-religious calculations.

However, there are none as unwise as those who think that God cannot comprehend the correlation between our statistics and our belief or sermons! This was the fault of some ministers during the apartheid years. Will we do better in future decades...?

PROF. RUSSEL BOTMAN

Vice-Rector (Education) University of Stellenbosch

President of the South African Council of Churches

Stellenbosch, 2005 


\section{CHAPTER 1}

\section{INTRODUCTION}

God for us. These three words summarise the core of the Gospel, as a salvific fact, consolation and promise. God's existence is existence for us, and our existence is existence through, and before, Him. Paul confesses this inclusively: God is for us (Rm 8:31), for Jew and non-Jew, without preferences or boundaries, for humans. In fact, the Gospel reveals that God vindicates humans of their sins, not on the basis of their abilities or virtue, but solely because they believe ( $\operatorname{Rm} 1: 16,17)$. Precisely because of this the Gospel is exclusive: then, "who can be against us?" ( $\mathrm{Rm} 8: 31$ ). These words apply against everything that is against us, also against us, who are repeatedly against God. They apply even against God's own opposition: through his wrath, God strives to reach us; in his judgement, He embraces us (Luther). Of this Paul is convinced, so convinced that, after his interpretation of the Gospel (Rm 1-8); he utters his cry of jubilation, and laughs his paschal laugh: God for us!

In this pro nobis lies also the meaning and secret of preaching. After all, in the Reformed tradition there is no conviction that has so strong an influence on preaching as, indeed, the doctrine of justification (Josuttis 1966:12). The proclamation of God turning towards us in Christ, of exoneration of sin through the Name of Jesus, that is the Gospel, says Luther, and, in the light of this, he lays down a basic rule that has become basic for all Reformed preaching: nihil nisi Christus praedicandus (proclaim nothing but Christ). The content of Scripture and the preaching are, in fact, summarised by the Reformists as: the Gospel of Jesus Christ (cf. Jonker 1976:61). Without this Gospel, i.e. without the actual justification of sinners by God in Christ, the sermon (regardless of its verbosity or correctness) will be vapour and noise, an empty speech, a lie, religious "bla-bla" (Bohren 1974:33). 
Within this basic Reformed framework, in this research I listened to 14 South African sermons and examined the nature of the declaration of justification and the character of the proclamation of the Gospel in each. Hopefully, this research will contribute towards an essential awareness-making process, namely of what happens in preaching when God is proclaimed as God-for-us - or not; it concerns the question: Do preachers actually mean what they say? And: Do they say what they mean? Often a few words, a single sentence, can negate the reassurance of the declaration of justification; often a mere change of "gears" of the biblical text sends the congregation home without the Gospel. In general, the preachers' theology is not so much apparent from their explicit dogmatic declarations, but rather in their sermons' spate of words, in their speech movement. They offer the highest degree of concreteness against which the preachers' theology can be tested. The nature of the spirit that inspires the preacher and the sermon is apparent from the torrent of words from the pulpit (Bohren 1991:3). Here, in the sermon's greater and smaller linguistic movement, much stands or falls, in fact everything!

However, this process of being made aware must not be viewed as clinical censure. The intention is to teach. After all, preaching is something that must be learnt, must be learnt anew every time. Our inherent inclination is to oppose the Word, and to oppose God's declaration of justification. We are for ourselves. All people, also preachers, are natural liars (Ps 116:11). While we want to do good also viewed homiletically - we do evil ( $\operatorname{Rm} 7: 19)$. This does not happen purposefully. Our bona fides are normally in order. We do not have preconceived intentions to tell lies (Augustine: mendacium est enunciato cum voluntate falsum enuntiandi). Yet, we do it. We use our language, which in itself is good and which the Spirit assesses as the most profound art (Grane 1971:191), so that it serves the lie, and only a narrow passage of truth remains (Weinrich 1970:12). We betray the truth with our rhetoric. I say "we" and mean exactly this. I know what I'm speaking about. I speak as a preacher.

Preaching must be learnt. The memory of history, as well as the history of preaching, is a teacher here. However, learning from this history is only meaningful if not merely the highlights, but also the preaching sins of yesterday, the shadows, are recognized and identified. In remembering this history of 
preaching, we develop caution in proclamation and confidence in proclaiming for the future. Discourse with the preaching fathers and mothers inspires us (Bohren 1981:48-69). However, this inspiration is preceded and is concomitant with confession. Unconfessed guilt is not like yesterday's snow. It does not melt as a result of our forgetfulness, but threatens to smother us if we suppress it (Bohren in preface to Richter-Böhne 1989). Our guilt must be revealed and be called by name, be brought to consciousness and be preached, and this is no easy task. To remember selectively is in our blood. We grow up with unilateral images of our history, about ourselves. We suffer from a natural inability to grieve about our sins (cf. Mitscherlich's 1967 study), including our homiletical sins against the congregation, and especially before God. Also, in this respect, this study wishes to be an awareness-maker, to promote self-insight, and to appeal for confession of guilt.

In view of this, I limit myself to sermons from the Dutch Reformed Church (DRC) for the reasons set out below.

$\sim$ The first reason is of an existential nature. I am a member - and was for many years a minister - of this Church. ${ }^{2}$ It is a well-known fact that, during the past number of years, the Dutch Reformed Church was called especially to confess its guilt for its theological support and promotion of the political system of apartheid. It has done so on a number of occasions, also formally during meetings of its General Synod. ${ }^{3}$ However, it still wrestles with this problem. For a variety of reasons there seem to be misunderstandings in this respect - underlined by the fact that even now, ten years after democracy, the Reformed Church Family is still struggling with the process of unifying. Some leaders of the Dutch Reformed Church still believe that the official synodical declarations and documents contain enough confessions and they blame other members of the Dutch Reformed family for being unforgiving and even appeal to them now to confess their guilt! It is clear that at least a part of the Dutch Reformed Church, particularly also members on grassroots level, do not understand the stance of the other members of the Reformed family.

\footnotetext{
2 The author is presently a lecturer in Homiletics and Liturgy at the Theological Faculty of Stellenbosch, South Africa.

3 First in 1986, and again in 1990.
} 
Possibly the Dutch Reformed Church does not realise how profoundly the other members of the family were affected by the system of apartheid; therefore they do not understand the need for a (continuous) confession of their guilt. Possibly some members of the family feel that the Dutch Reformed Church has not reached the true point in its confession. The issue of guilt, restitution and unity is a continuing debate at present in the South African church scene, and will probably remain so for years to come. ${ }^{4}$

This research wishes to serve this discourse, wishes to provide contents for it from a homiletical perspective, and especially wishes to contribute to the content of the confession of guilt as such, a concept that runs the risk of remaining vague and academic. That the DRC has a reason for confession of guilt, in my opinion, is apparent from the analyses. The sermons at issue here demonstrate, beside all the positive things that one could say about them, and despite all the biblical and general Christian truths that they also contain, that here something happened with God Himself, that something was made with, and from Him that affects the heartbeat of the Gospel. How the DRC will deal with this fact will, in my opinion, greatly determine its future credibility. This is an issue that cannot be settled with a number of official declarations, but which must be worked through in continuous discussions in a process of questioning and listening, of remembrance and repetition, instead of forgetting and pushing aside (Richter-Böhne 1989:13). There can be no other route.

$\sim$ The second reason for limiting myself to the DRC sermons is practical by nature. During my doctoral studies ("Soos woorde van God," 1982) I analysed, inter alia, quite a number of "political" sermons that ultimately were not included in the dissertation, but which offered fascinating reading. I have extended this "bank of sermons" in this study and offer the broader background from which I made the selection of 14 sermons, an indication

The DRC and the URC (The Uniting Reformed Church in Southern Africa) are presently engaged in talks and conventions concerning unity. There are, however, still a number of unresolved issues, for example, the acceptance of the Belhar Confession by the DRC. 
that the phenomena that I highlight here are not merely exceptions to the rule, but deserve further and incisive attention.

$\sim$ The final reason is a matter of principle. Although one can accept with confidence that not only the DRC preached in this manner, and that the Hervormde and Reformed Churches ${ }^{5}$ also contributed to the creation of a specific viewpoint among members, the general acceptance is that the DRC was, and probably still is, the greatest and most influential Church among white South Africans. Thus, this Church represents an important "homiletical agent" and therefore also an important contributor to the present situation.

In formal terms, the purpose of this study is to assess the hermeneutical method of sermons by means of rhetorical and theological criteria, in order to determine the processes that the preachers followed to articulate God as God-for-us (pro nobis). The sermons all are from the period 1960 to 1980, an era in South African history that, on the one hand, was still characterized by a post-war prosperity among a large part of the white population, and on the other hand, by growing relational problems and alienation among the various population groups. In this respect, the events at Sharpeville (1960) formed a type of watershed and focused the world's attention on South Africa, with increasing foreign isolation, sanctions and internal unrest and violence. (For an extensive discussion, cf. Muller 1980:510-520.) South Africa's subsequent withdrawal from the Commonwealth (May 1961) led to its greatest economic crisis since the depression of 1930 to 1932. A combination of political, economic and social factors resulted in experiences of anxiety amongst a section of especially the whites, who felt that their identity and continued existence was threatened. In many respects, it was a time of upheaval in which the "white" church wished to guide its members pastorally, also in their preaching. The sermons that are at issue here must be understood in this light as sermons that had the explicit or implicit intention to be relevant by uttering a timely word of reassurance for that troubled era. In a

\footnotetext{
5 Other churches within the Reformed Family, which either explicitly or implicitly advanced the notion of apartheid in South Africa.
} 
sense, these sermons expressed the religious interpretation of the "people's" state of emergency; they expressed a search for religious anchors, for consolation and thus could be called pastoral preaching to the people.

Therefore, the broad coordinating system within which the sermons could be placed is the experience of threat and anxiety, on the one hand, and on the other hand, the intention to define theologically the "people's" situation and, indeed, justify it, as the analyses indicate. The hermeneutical choices and short-circuiting that emanated from this threat are assessed with the help of linguistic and theological criteria.

Thus, the theological tradition pertaining to the sermons are Reformed; in fact, all are from Die Kerkbode, the official paper of the DRC, but they in no way represent an exact image statistically of all preaching from this time. The research does not wish to say: this is typical of sermons in South Africa, or in Die Kerkbode, during these years. But it can indeed say: this is what was preached too. Naturally, there were also other voices that expressed the "people's situation" completely differently. ${ }^{7}$ There were also sermons - perhaps the majority - that made no mention of the situation. Yet it is significant that this period's "threat" was expressed particularly strongly in the analyzed sermons, and that the fear and uncertainty attained an unmistakably urgent character. Here there are clear signs that the old traditions have come under attack as never before, that they indeed were beginning to crumble. These factors played a decisive role as norm for the selection of the sermons, in the sense that sermons were selected that strongly addressed the above-named two poles, i.e. the external threat, on the one hand, and religious "solutions", on the other. The number of sermons that ultimately were included in the study is incidental. I may mention that, interestingly, among

\footnotetext{
6 The Afrikaans word "volk" is a key concept in these sermons. "Volk" could be translated as "people" or "nation", but implicitly referred to the white Afrikaner as an ethnic group.

One need only mention the prophetic ministry of Beyers Naudé - to name but one - who grew up in the typical Afrikaner establishment, but soon realised that the system of apartheid was biblically and morally unjustifiable, and protested against it in his preaching, declarations and actions.
} 
the 14 sermons, two were held on the Day of the Covenant, ${ }^{8}$ one was a message at the celebration of Republic Day, one was given as opening address of a General Synod of the DRC, and two were New Year's Eve/New Year's Day sermons. The Afrikaans sermons were translated into English in order to introduce this genre of preaching to a wider audience. The translation strives to retain the original grammatical structures and idiomatic expressions as far as possible.

One could rightly accept that this genre of preaching exercised a significant influence on the viewpoint, not only of local congregations, but also on the broader population among whom the DRC worked. The role of the preaching, as opinion-maker, must be neither over- nor under-estimated, especially as regards the legitimizing and perpetuation of existing religious and social profiles. The preaching was often merely a mirror image of the community that it served (Müller 1987:43-44). The young democracy of South Africa, which is characterized by transition - and thus uncertainty - does not come out of a vacuum. It was preceded by traditions that, inter alia, were also protected by this preaching, but are now being replaced by new ones. However, old traditions die slowly. The after-effects of the preaching of the years 1960 to 1980 are still perceptible; the present South Africa is also its fruit. To a certain extent the sermons, with their strong protest against change, which sometimes borders on the creation of an apocalyptic mood, express the first birth pains of a community in transition, and illustrate the escalation of disillusionment with the order then prevailing.

Therefore, although the sermons deal with various biblical texts, it is not surprising that the hermeneutically determined foundation is precisely identical, with a few exceptions. A single glance at the choice of texts of the sermons confirms this: texts in which times of crises were reflected, mainly Old Testament texts in which the political and theological viewpoints of the Israelites were connected, enjoyed preference, as they most effectively facilitated the association between the nation's situation and religious interpretation (cf. Pressel 1967:40-

\footnotetext{
8 A religious festival upheld by a section of the Afrikaner people, celebrating their forefather's victory on the battlefield against all odds against the Zulu people. God was given the honour for this and a covenant made to celebrate this day as a Sabbath. Currently it is a public holiday known as The Day of Reconciliation (16 December).
} 
41). The sermons also often express concern about the youth, who had to maintain the traditions and thus be anchored in the old order. All new influences had to be kept from them. Conservatism was to be preserved at all cost.

This structure, in which all the elements are actually interwoven and confirm each other, forms a close unity in all the sermons. The reader could probably also recognize a similar structure in other periods and in other sermons of this kind. In fact, it is possible that we are not dealing here with a specifically Dutch Reformed or South African phenomenon. Situations of anxiety in which ministers and their congregations find themselves may differ from time to time, may present totally other features, but the hermeneutical way that is followed to conquer anxiety is stereotypical. ${ }^{9}$ The basis of these 14 sermons, preached between 1960 and 1980, offers a grasp on a wider phenomenon.

In the research I used the analytical method that the theologian, Rudolf Bohren, and the German author, Gerd Debus, developed at the University of Heidelberg in Germany (summarized briefly in Bohren 1989:55-61). This method gained international recognition at a symposium on preaching research that was held from 8 to 12 September 1986 in Heidelberg. To my knowledge, this is the first time that the method has been applied in this way to South African sermons. It developed from the close reading of literally thousands of sermons and takes as its point of departure the right and power of a congregation (as ecclesia completa) to corroborate critically the preaching taking place in its midst. The objective is for the method to act as an aid for this congregational assessment of preaching (cf. Cilliers 1992:383-389).

The Ecumenical Association for the Promotion of Preaching is refining this method continuously. It has its seat in Heidelberg and has a sermon bank of over 20000 sermons from a broad spectrum of theological and ecclesiastical confessions from, inter alia, World War II as well as the post-war period, when issues such as guilt and restitution had to be dealt with. Thus, it is a method that grew from a sensitivity to the history of preaching, but also a passion to move closer to the practice of preaching, and as such it represents an integrated

\footnotetext{
9 For example, a study on the way congregations and churches are presently dealing with different forms of anxiety in the young democracy of South Africa would be illuminating.
} 
practical theology in its own right. However, as a methodology it does not want to be an objective in itself. It wants to contribute to the theological and empirical evaluation of preaching and to be used to supplement methods that place a greater emphasis on an investigation into the communicative working of preaching (cf. Pieterse 1991 for an extensive bibliography).

In co-operation with the Association, these sermons were analysed during ten meetings. The analytical team was comprised of theologians and ministers of the Lutheran Evangelical and Roman Catholic Churches, as well as a number of doctoral students and lay preachers. The most important findings of these sessions, as well as many personal discussions with members of the Association, are reflected briefly here and thus offer a broader, ecumenical vision on this specific form of preaching (cf, also Chapter 5 on the ecumene).

Formally, the methodology consists of a number of analytical and synthesising steps. On the one hand, the text of the sermon is examined in extenso - its content is investigated linguistically (regarding words, sentences, paragraphs) so that the superficial structure becomes clear. On the other hand, the mutual relations between the linguistic contents are determined in order to allow the basic motives of the sermon to be revealed. These motives together form the depth structure of the sermon.

Here I use the terms "superficial structure" and "depth structure" as they have become part and parcel of the terminology of the Ecumenical Association. These terms have a particular linguistic content and definition, and appear as such in discourse analysis. Here, the issue dealt with is the difference between the explicit and implicit use of language, which offers the possibility to critically interpret the sermons ideologically. Research has shown that the formation of ideologies takes place at various levels. The level of depth, which Faye (1977:142) calls the real intentions and interests of the ideology, mostly determines the surface of the discourse, which can include matters such as reports, ideas, propaganda, promises, rhetoric, etc. To serve these intentions and interests, ideology needs instruments of power and it is especially the power of language that is mobilized in this respect. Ideology is the use of meaning (thus language) in service of power (Thompson 1984:131-132). Therefore, the study of ideology is synonymous with the study of the ways in which language is applied to sanction the relations of 
domination, and it is the task of ideological criticism to point out the other possibilities of language, i.e. to break through the existing reality of language being used as an instrument of power, to relativize the existing power relations and to propose new realities. In fact, ideological criticism not only points out this possibility, but already demonstrates it (Thompson 1984:131). Thompson distinguishes three ways in particular in which ideology operates in, and through, language: firstly, by presenting the relation of domination as legitimate. Every system of domination tries to build faith in its legitimacy by an appeal to either rational, traditional or charismatic grounds - an appeal that is normally expressed in language. The second is by way of dissimulation. Relations of domination that serve the interests of some to the detriment of others are hidden, denied or blocked in various ways. These processes, which often overlap and seldom take place deliberately, conceal themselves by presenting themselves in a number of ways that are implemented to hide their true nature. The third method is by way of perpetuation, i.e. by changing a transient, historical situation into a permanent, natural, non-temporary premise. According to Thompson (1984:131), the role of ideology possibly lies especially in this: to (frequently) reconfirm the idea of a community "without a history" in the centre of the historical society.

According to Thompson (1984:131-132), these three linguistic modi operandi of ideology formation are not necessarily the only ones that figure in a given situation, and they are also not mutually exclusive. By way of theoretical and empirical analyses, the unique interplay of these and other factors must be discovered in each situation. All this requires an intensive work with language itself. On this, Kress and Hodge (1988) did pioneer work in their search on the social dimensions of semiotics. According to them, semiotics has a social function in the sense that it offers characteristics according to which the identity and cohesion of a group, as well as the distinction from other groups, are illustrated and promoted. These signs (Hodge \& Kress also call them metasigns) thus express a specific view of social relations and continuously monitor these relations of the "semiotic group." Hodge \& Kress distinguish a whole constellation of metasigns that have definitive social, and therefore ideological, functions (1988:78-120). 
The Heidelberg method of sermon analysis seeks to reveal the explicit and implicit signs of language in sermons. It meticulously notes finer speech signals, for example:

$\sim$ the introductory sentence(s), because they mostly determine the course of the sermon;

$\sim$ the conclusion, because this indicates how the expectations raised in the first sentence(s) are fulfilled;

$\sim$ the way in which words in the building up of the sermon are grouped together or are stated in contrast to one another;

conditional sentences that reveal the active powers in the sermon;

$\sim$ emphases, because they often in fact express uncertainty, and often lead to logical breaks or conflicts in the sermon;

negations, because they make those issues that the sermons are confronting important, because they adjust positions, etc. (cf. Bohren 1989:60).

In the process, not only does the method interrogate the sermon text about what it says, but also about what is not said, what is excluded, pushed aside, transferred and even denied by what was said. This enquiry into the inner dynamics of the text is systematized with the assistance of four basic homiletical questions, i.e.:

Which God is at issue here? What are this God's characteristics and how does He behave?

$\sim$ How is the biblical text included in the sermon? And, in keeping with the particular interest of this study: How does it express the Gospel of justification through grace?

$\sim$ What kind of congregation does the sermon appeal to and imply? What is the relation to the world/other groups?

$\sim$ How does the preacher him-/herself function in the sermon?

The study of the interaction between the superficial and the depth structures, between explicit and implicit language, offers the potential to interpret the sermon theologically. In this way text-immanent analysis and theological interpretation form the instruments through which the sermon, as a linguistic and theological unit, is heard. The homiletical-theological framework within 
which this takes place in this study is mainly that of Rudolf Bohren (cf. 1971:3ff), which, inter alia, rests strongly on Reformed insights into the nature of preaching. The methodology questions the quality of texts, and does not claim omniscience regarding the true working of sermons. After all, methods, rhetoric or letters on paper do not limit the Spirit. The Spirit works. Herein lie the boundaries, but also the promises, of such research. It accepts preachers at their word in an attempt to understand them, perhaps to understand them better than they understood themselves. In this case, it wishes to understand the preachers' sermons theologically. Therefore, it questions the inner logic of the sermons, as apparent from each concrete text preached, and carries this to its uttermost logical conclusion; it enters the sermon through the doorway of the superficial structure and seeks out the depth structure and decisive associations in order to understand and evaluate the true driving forces and motives of the sermons.

Here too, we do not pretend that the methodology has at its disposal untainted objectivity. Like humans, texts are a secret, a living phenomenon with many facets. We do not know everything about texts and we do not know everything about humans. The exposer of the depth structures of a text can neither claim a final word on the "purpose" of the author, nor the "meaning" of the text. At most, an analysis is an explication of how he/she interprets the relations between the constituents of the text (cf. Deist 1978:264) - an interpretation that needs the control and enrichment of other analysts (cf. also Chapter 5). Therefore, the methodology distinguishes between analysis and interpretation, but does not separate them. Every analysis is already an interpretation, therefore contextual. Also the analyst often wants to do what is good, but does not do so (cf. Rm 7). Therefore, the analysis and interpretation are meant as the enquiry of a brother or sister into the works of brothers and sisters, as an attempt to hear, and to hear whether others also hear the same, as a discourse on the preaching, thus on the Word of God Himself.

The analyses that follow must be read in this light. Some interpretations may sound drastic. They have not been conducted lightly, nor do they derive from a lack of respect for the church or its preachers - on the contrary. I expect much from the church, specifically the DRC. Perhaps this explains my grief about a great part of the analyses. The reader is entitled to differ from me in this. As long 
as the issue at stake, namely the preaching of Scripture in our South African society, is taken seriously, as it were, through new and sensitized eyes.

The first round examines the way in which particular historical traditions function and their influence on the use of the biblical text and the image of God. Here we examine the first hermeneutical step that is taken in these sermons, namely backwards into, and eventually out of, history.

Secondly, the proclamation of the law and the Gospel, and consequently their effect on Christology and ecclesiology, are scrutinized. We take a closer look at the second hermeneutical step in the sermons: inwards, into the potential of the "people's" soul.

Thirdly, the study reflects on the homiletical and hermeneutical role of guilt and anxiety. In this round the third hermeneutical step is scrutinized: outwards, with the projection of guilt.

The final chapter reaches a few conclusions and proposes solutions.

In order to allow the preachers themselves to speak as far as possible, there are extensive excerpts from their sermons. The sermons are analysed respectively as texts, but also as a collective text, as a co-text, that conveys one message. The point of departure is that each sermon's text is an intertext, ${ }^{10}$ i.e. that it is embedded and woven into the wider context of society and here, in particular, South African society during the years 1960 to 1980. Thus, as texts, they could not be approached atomistically, but as part of a more extensive genre of proclamation.

Shorter citations are sometimes used to elucidate other longer quotations and analyses. This takes place against the background of the incisive analysis that has been made of all the sermons.

10 The concept of intertextuality derives from linguistics, in particular the philosophy of deconstruction, which has its roots in Derrida's work (cf. Kearny 1986:113-133). There are many shared levels between deconstruction and the methodology of sermon analysis that have been applied here, for example, the demythologizing of transhistorical projections, the relativization of interpretation processes, the creative play with the text, etc. (cf. Degenaar 1986:106). In my opinion, it is of the utmost importance that the church uses retrospection to analyse and reveal the destructive myth(s) that was rife in this period, in order to gain wisdom and foresight for the future. 


\section{THE FIRST HERMENEUTICAL STEP: BACKWARDS INTO, AND OUT OF, HISTORY}

The most general and indeed decisive structure for understanding the analysed sermons is the situational analogy that is presumed between current and biblical times. Its basic point of departure is: what applied then, also applies to us; what God did or asked of humans then, also applies in our times. Applied to a person, it reads: as it happened to this or that biblical figure, it also happens to contemporary people in their encounter with God (Josuttis 1966:23).

Therefore, the hinges on which such an analogous scheme revolve are often expressions such as: "Thus, precisely thus, it also is today"; "We are also ..."; "Exactly so our people also ..."; "Like the Jewish people, our people also ..."; "Our times and circumstances are not very different than in Noah's time," etc. The purpose is to say: what we now experience is not unique - others have already experienced it. This aims to indicate that the respective times, in reality, are identical, and, in so doing, to try to place one's own situation and time within the salvific-historical perspective. The use of this analogous scheme is symptomatic of a search for security in a time of emergency. The basic presumption of this is that the actuality of God's Word depends on the parallelism of historically comparable situations and the conformity of general anthropological structures. Therefore, preaching must seek similarities, identifications, comparisons and examples to serve as a current consolation and appeal.

Greidanus did extensive research on the distinction between exemplary and salvific-historical preaching. According to him, exemplary preaching breaks up the one history of salvation into many histories, many stories. This fragmentation 
of Scripture and salvific history compels the preacher to seek the link between the past and present in an (unhistorical) analogy. Thus, biblical figures are presented as examples from the past to fulfil a positive or negative function in the preacher's striving towards actualization. Biographical preaching of this nature, however, is anthropocentric and results in biblical texts with a specific focus becoming optional or at least interchangeable. In addition, there is also the reality that these examples are not exactly apt for our situations: in fact, the historical gap contradicts every attempt to apply them directly; the historical ballast clinging to them prevents a smooth equalization. Then, the exemplary recourse is to build a bridge between the past and present by way of an atomistic interpretation: not the entire person, but merely a few "atoms" of his/her existence and behaviour are applied selectively. Normally, the methods of atomization are psychologizing, spiritualizing, moralizing and typologizing. However, according to Greidanus, the selection of these atoms is arbitrary and subjective. It also represents a further dehistorization of the biblical text, as all these analogies are inclined to raise a single atom from the flow of history and to place it in a sphere of timeless structural equalization. Although the exponents of the exemplary method certainly are not so naïve to believe that the historical past and the present are literal duplicates of one another, this is, in fact, what happens in this method. The past is made equivalent to the present. The point of departure of the exemplary method is that the people in the biblical text are regarded as mere mirrors of us today (i.e. that they do not have an individual, historical right and existence), and that we recognize ourselves in them. However, the power of history cracks this exemplary mirror. Exemplary preaching is a homiletical shortcut past the historicity of the biblical text, resulting in a hermeneutical, and mostly moralistic, short-circuit (Greidanus 1970:85-86).

Thus, when such an analogia situs is applied in preaching, this must be done with the utmost care. Scripture itself often appeals to remembrance, which presumes a particular link between the present and the past, as, for example, the closing of a new covenant (Jer 31:31-34). However, then it is indeed a new covenant, with unique characteristics and stipulations, a new piece of unfolding history (cf. Bohren 1974:159ff on the homiletical implications). Therefore, the contingent nature of historical situations must not be over-emphasized so that all possibilities for communication between the past and present are excluded. The 
link can be sought in terms of analogies, but then this must be done by way of an integrated process of interpretation. In other words, the biblical text must still be dealt with as a unit, not as a collection of loose elements. In such an approach, all the principles that apply for the exegesis of a biblical text as a historical text must be present (cf. Greidanus 1970:214-234). Historical situations are complex. Therefore, analogies are problematic, not because they are incidental. Thus, here, by "contingency," I do not mean that the biblical situations are so incidental, so accidental, that we can learn nothing more from history, or about God, as, for example, historicism advocates. On the contrary, history in fact proves that God is unchangeably changeable! However, the problem resides in the fact that the sermons decomplicate historical situations by way of unilateral analogies, that they transfer a few aspects with specific viewpoints to the present situation of the "nation."

Therefore, the opposite must also be stated: scripture is a historical document that speaks about God's actions in the past in non-interchangeable, specific circumstances, which form the concrete presumption for the concrete proclamation of God's great deeds. As such, it is history and non-recurring. Those who wish this to recur must, in the present, reconstruct not only the proclamation, but also the situation in which the proclamation took place, as the one is not put on record without the other in Scripture. However, this is no easy matter and can lead to analogies being presented as cosmetic and forced (Josuttis 1966:24). Historical situations can only be compared in extraordinary cases, and existential structures mostly adopt the concrete contours of specific, nonrecurrent situations. History - also the history of salvation - is unique; human situations, their political relations, religious problems and social worlds are difficult to reproduce exactly. This tension between the letter of Scripture as proclamation of the Name of God in certain circumstances, and the Spirit as the presence of the Named, may not be solved unilaterally by a biblicist overevaluation of Scripture. Scripture rather offers a type of working hypothesis: for us, it spells out God's Name and invites us to also spell it, read it and proclaim it in the hope of the re-amalgamation of the Name and the Named. In this respect, Scripture is not a monolithic block of God-speech that can be forced fundamentally on certain situations (Deist 1991:378). It rather is the school of the 
Holy Spirit (Calvin), with a double function: it serves as a criterion for the distinction of the spirits and as medium of salvation; and it illustrates how God acted and becomes the medium through which God acts again (Bohren 1974:110113). Therefore, there is a distinction between Scripture and God's word. The latter is the prerogative of God's Spirit, without which the Bible and the sermon remain dead letters. A unilateral solution of this tension mostly turns back on itself with profound theological consequences.

Now, let us turn our attention to the first analysed sermon.

The abovementioned use of analogy becomes clear in a sermon based on Nehemiah 4:14. The preacher wants to parallelize the threat from the Samaritans to the Jews with the threat to what he first calls the "church", then "Christendom", the "Christian religion" and what he ultimately describes as "the South African situation" and the "pattern of life in our land." He does this with reference to the words of the text: "Don't be afraid of them. Remember the Lord, who is great and awesome, and fight for your brothers, your sons and your daughters, your wives and your homes."

The first paragraphs of the sermon determine the subsequent exposition of the biblical text. It goes like this:

"Times in the life of a church come when it must blow the trumpet without fear - or has to follow the more difficult path to its own downfall. In such times, the church must ask itself anew, in the light of the Word of God, where it is heading. And if it chooses the way of being faithful to its calling and to Scripture, then it must prepare itself for most aggressive resistance.

"In this struggle there will be journalists who will dip their pens in poison; trusting members who will be misled; as well as misunderstandings and quarrels, casting of suspicion and malignance.

"And, if the church is driven out to the desert of isolation as a result of its taking a stand and stating its views, then it must remember 
that isolation, as such, is no sin. Two thousand years ago the Lord Jesus and his small group of followers were the most isolated community of that time - and of all times."

The first sentence contains an alternative that eliminates all other possibilities syntactically; strengthened with the compelling "must" that is repeated three times, with rising tension, in the first paragraph. The preacher wants to point out the threatening "downfall" and, by the phrase "where it is heading," suggests that the church has already taken the first step along the easier road to "downfall". Now, the trumpet is silent. The conditional construction of "most aggressive resistance" illustrates the terrible situation: "And if ... then it must" in which the "church" must fulfil the condition (cf. Chapter 3 on the function of conditional sentences). This is precisely the situation that the preacher has in mind, for which he wants to prepare the congregation in the sermon, and which forms the one pole in his analogy.

The second and third paragraphs follow with a description of the "struggle" in which the "faithful members" will be "misled" and the church will be "driven out to the desert of isolation." Here, the "isolation" is the result of external forces, as well as the fulfilment of (biblical) conditions by "the church." This is sanctioned when the preacher bases the inevitable isolation that comes over the "church" on Christology. The isolation of the "Lord Jesus and his small group of followers" becomes the legitimization for the isolation of South Africa with its "pattern of life" as described further in the sermon. The implication is: isolation must come, but is justified; God is for us in our challenge, and against all who isolate us and are against us.

This justification for the current situation of South Africa is strengthened when the preacher brings the other pole in the analogy into focus. In this respect he makes two significant remarks:

"And then, in a surprising way, a pattern of action follows that links Nehemiah's time and our own time. The past suddenly becomes the present, when the Samaritan strategy is described verse by verse. 
"And now ... have I occupied myself merely with a small section of antique history? Or are these patterns illustrated on the walls of our time? Are they written in the news columns of the papers of yesterday and the day before? Do we read them in the ecclesiastical manifestos and theological documents of today? Is history repeating itself, repeating itself with alarming consequences?

The preacher intends to say: the attack against South Africa is nothing new; it has a negative parallel in the history of Israel. With the help of rhetorical questions, the congregation is informed of the possibility/reality of history repeating itself. This places the preacher himself before a dilemma. If the current situation is precisely like that in ancient times, does this imply that God will act precisely as He did then? Will not only history, but also God repeat Himself? Are his actions determined today by this situational analogy? If this is the implication, then the preacher runs the risk of falling into an automatist scheme and God image. This is a logical consequence of the analogy.

The purpose of this analogical schematism is good. It expresses the preacher's search for the meaning of the Gospel and, in this way, he wishes to evaluate and elevate the current time as a time of salvation. Yet it has exactly the opposite effect; in fact, it destroys time as salvific time, by it affecting the dialectic relation between God and time in its core. For a better focus on the consequences of this process of destruction, i.e. the loss of God in the analogy and the change of the sermon as expression of the Word of the speaking God (dei loquentis personae, Calvin) into a populist speech, it is important to make a few comments on the relation between God and the time.

In this relation, on the one hand, God enters time; on the other, He remains the Eternal - his Being is one of constancy and variation. Let me explain this in some detail.

On the one hand, God works so contextually, He is so varied in his Epiphanies, that one must, for example, emphasize with the biblical writers that it is the same Jesus who appeared in the fullness of time: Jesus Christ is yesterday and today the same until eternity (Heb 13:8). The strangeness, the incomparableness of the 
Name of God (God is identical with his Name: Nomen Dei est Deus ipse), indeed, is in keeping with this chequered way of appearing, with the fact that He indeed makes history, always new and surprising (Bohren 1974:100).

Both the Old as well as the New Testaments express God's history-making action predominantly with the help of linear time categories. ${ }^{11}$ The linear passing of time (history) thus is not conceived as an abstract continuity of time, but rather as the God-given content of certain moments in history. God's objectives for the world move to a consummation; things do not just go ahead or return to the point where they began. Although the fall of humanity made history meaningless and monotonous, it is indeed God's intervention that (always) imparts purpose and new meaning. Linear time is not a sequence of inevitable events, but moments, "days," in which God brings his objective for the world closer to its conclusion. These are unrepeatable moments, kairos moments, in which God allows a specific objective to be fulfilled at a specific time. The fullness of time, with Christ's coming, the ephapax of his crucifixion, is the most striking example of this (Kümmel 1974:141-146).

Therefore, one must also emphasize that God is the Lord of time and history, ${ }^{12}$ that He is the eternal King (1 Tim 1:17). He determines, divides and encompasses time, ante et post Christum natum. Before Him there is but one time, and one day is like a thousand years and a thousand years like one day (2 Pet 3:8). He sees through time, as the Alpha and the Omega, the One who is, who was and who is to come, the Almighty (Rev 1:8). In the Holy Spirit, He closes the book on certain periods of time, and in doing so creates new time: therefore from now onwards we no longer judge anybody according to human criteria; now we no longer judge Him thus (2 Cor 5:16).

\footnotetext{
${ }^{11}$ In some instances, for example in the Wisdom tradition, we do find the concept of cyclical time. In my view, this does not oppose the notion of linear time. Within linear time there are certain occurrences that repeat themselves, for example the seasons, but these repetitions are never understood as the inevitable, unpredictable fruits of fate. Cyclical events can be seen as part of the linear movement towards the Day of the Lord, even if this Day sees many fulfilments.

${ }^{12}$ Here there is a distinction between time and history, but not a separation. Viewed formally, time is God's gift to humans as a possibility for existence (Barth); history is the actual course of time.
} 
Both these aspects of God's actions with us must thus be maintained, i.e. his transcendence and his immanence. Indeed, God reveals Himself in history, and this is no deceptive revelation, but his Being that He reveals to us; it is He Himself who makes history in his revelation. Between God's Being and his revelation, there is no tension. Yet God is also more than his revelation. God's reality is not dissolved in his work. Because He is more than his works, He can work; because He is greater than his revelation and precedes it, He can reveal Himself (Durand 1976:47). Neither has God, in his revelation, been given to us as manipulable in our hands. His Name remains a nameless Name (Miskotte 1965:99-111).

As the proclamation of this nameless Name, preaching stands in precisely this tension. On the one hand, it needs Scripture that is a historically fixed chronicle, a concrete documentation of God's actions in history. On the other hand, preaching lives as a promise that belongs from case to case to the moment, to the kairos of God's new activity. Therefore, preaching is never a mere repetition of biblical texts, but it always interprets the (present) time as a time of grace and judgement: "In the time of my favour I heard you, and in the day of salvation I helped you" (2 Cor 6:2); "Now is the time for judgment on this world: now the prince of this world will be driven out" (Jh 12:31; cf. also 1 Pt 4:17).

Such an interpretation of time demands a dangerous undertaking, the dangerous undertaking of preaching. It demands prayer. It demands prophecy. It articulates the fact that the hour of salvation has struck, and thus drives time ahead (cf. $1 \mathrm{Pt}$ 3:12a). As such, preaching is possible, yet not possible; it is art, yet not art; as an articulation of the Name, it depends on the assumption that God Himself must legitimize the preaching, lest the wonder of preaching be negated (Bohren 1974:93). Preaching aims at re-uniting the Name of God (God Himself) and the One named in Scripture - primarily then, a Name address and, as such, a biblical address. Strictly speaking, we do not proclaim texts, but the Name of God. We proclaim Him who is eternal, the same yesterday, today and until eternity. Therefore, Manfred Josuttis significantly comments that the historical distance between the Bible and its chronicled activities of God, on the one hand, and preaching, as proclamation of His great deeds, hic et nunc, on the other hand, can be bridged only with the help of doctrine - specifically the doctrine of God as the most internal nerve of theology. This is so because the secret of preaching, 
indeed, lies in the Name of God (Josuttis 1966:27), but then not so that it is a mere addendum (cf. Chapter 3), but rather that it fulfils a fundamental, hermeneutical function. In fact, if the Name of God is muzzled in any way, there hermeneutics become dumb, or at least serve other interests than those of the biblical text.

The analogical schematism dispels unilaterally the tension that characterizes the dialectic relation between God and time. Instead of the eternal God, Father, Son and Holy Spirit being proclaimed as the One who acts in the relative times, $\mathrm{He}$ becomes bound and thus idolized in the relative times. By implication, He is divided into two. On the one hand, He is written into an ancient situation (e.g. $300 \mathrm{BC}$ ). On the other hand, he becomes trapped in the present day. Strictly speaking, He cannot act freshly and differently. Ironically, by his being so trapped in history and in proclamation, He is taken from history and his Sovereignty over history is taken from Him. If I interpret this correctly, through this, He becomes an unhistorical principle. Apparently, in the case of the analyzed sermons, Reformed preachers here took a few deep swallows from a source beside the Bible, namely Plato's ontology (cf. Deist 1991:369)!

Actually, this kind of analogical schematism is a way of escaping from time, from the continuation of time, and from God's self-revelation in time; it is a grasping back into history to avoid contemporary realities and the future. It represents a particular form of anti-prophecy that does not dare to jump ahead, but rather arrests time and reproduces history. In this arrest and reproduction, God becomes comparable and inactive. However, God is precisely the opposite: He is the incomparable active One (Wolf 1969:400ff), because He is distinct from all gods, powers of nature, historical events, or the world's primeval functions. He is not similar to the world's objects and powers; also not identical to people, their groups or human behaviour. He is the free ground of all that exists and takes place. In no way is He subject to repetition, but is the living One who frequently is defined as such - and only by Himself. In this resides His total difference: that between us and Him there is an infinite qualitative distinction that can be bridged only in Christ and through the Spirit "straight from above" (Barth 1971:171). His reality negates the gods of the world's reality. God is incomparably different, especially in that He cannot be moulded in an image. 
In my opinion, in the analogical schematism a set image develops, of history, humans and of God. Unique situations and events, and eventually God himself, become de-complicated and fixed in time. This occurs by means of the image that is formed of the past and adapted to the present, and vice versa. Because the images of the past and the present must fit, must be identical, both become false, i.e. $a$ loss of the reality of both the past and the present takes place (cf. Pressel 1967:352). In their place, this constructed and set image emerges, an unchanging and therefore false image.

By this I do not imply that we can preach without images, i.e. without interpretations of history. In our view of reality, we are not tabula rasa. In fact, we receive history; hear history merely as told and retold history. The biblical text itself is an image and an interpretation of the reality of salvation. After all, it is a remembrance of this reality, proclamation of it in a specific situation, a prophetic aspect of the salvific reality, and a particular viewpoint of the greater, biblical horizon. Therefore, strictly speaking, preaching is already a meta-image of this comprehensive reality of salvation.

For example, Jungel writes extensively on the meaning of "metaphoric truth," or the "theological relevance of the metaphor." According to him, religious communication - also that of the Christian faith - attributes more to reality than what actually applies to the situation. However, this need be no "lie" should the correct metaphorical critique always be applied, namely the "story" of Jesus' life, death and resurrection as events which redeem sinners. In these events lie the ground and the boundaries for the implementation of theological metaphors (Jungel 1974:116). Within this norm, metaphorical speech verbalizes aspects of the reality that do not (yet) exist and, as such, it speaks of "the truth." So, metaphors call into remembrance in such a way that they open new perspectives for the future. They create something new through history being retold for a specific audience and with specific purposes. For the audience, it becomes a concentration of time ("Ballungen von Zeit"); it presents what was so contemporary that something new could be said. This form of memory leads to discoveries and enables one to "see everything with new eyes" (1974:116).

Thus, in preaching, it is of cardinal importance that one frequently asks: what "story" (history) is being told to whom and why? A study of the analogical 
schematism, as it functions in these sermons, illustrates that a single aspect of the told salvific reality has become fixated and abstracted, normally with a reduction of the biblical horizon, with the objective of justifying the present situation. The biblical image must cover the contemporary image. In the process the (told) reality becomes a comparison with one point, instead of an analogy that honours the complexity of the ancient situation and that of today. The causal point of comparison becomes the punctus solus - that transcends reality, or at least the proclaimed reality. A point, an aspect becomes abstracted, is lifted from its contingent coherence and is turned into a stringent principle. Thus, it is overlooked that the ancient "homiletical situation" and that of today are contextual situations that were and are determined by many contemporary factors, such as the macrocosm (Lange 1976:38: "Grosswetterlage"), the social order and life; the political events and ideas of the day, and especially their influence on people: anxiety, hope, resignation, feelings of powerlessness against the great social processes, etc. These broader factors change continually and escape any form of fixation.

That the analogical schematism fixates certain aspects is evident from the way in which God and humans are viewed and described (cf. Chapter 3). This fixation can, however, also be revealed linguistically in the light of the way in which Scripture functions in preaching. Normally, a stereotypical adaptation of the biblical text and selective citation from it takes place. The fixation and abstraction of a particular aspect of history has its counterpart in the reduction of the biblical text.

As an example, let us look at a Day of the Covenant sermon based on Ezekiel 37:1-14.

An analogy is drawn between the skeletons of Israel that God awakened to be living organisms and the Afrikaner people who gradually attained their identity. In the process the preacher forces direct links between Israel and the Afrikaner: the prophet Ezekiel expresses the situation of the "people." "In doubt," he answers the Lord's question - reflecting the uncertainty of the Afrikaner. The word of the Lord (full of promises) to the prophet Ezekiel becomes a "warning word also for us: Child of man, these dry skeletons are the house of the Afrikaner people." The 
pedagogic purpose is to provide the listener with an insightful view into the "real situation" in which the Afrikaner nation lives, etc.

The way in which the preacher omits certain texts and combines others is significant. For example, verses 4 to 6 are initially left out, and then verse 6 is added, but in a shortened form. The phrase "that you again become alive" is replaced with an ellipse as, here, in the introduction to the sermon, it probably hampers the analogy between Israel's skeletons and that of the Afrikaner nation. Verses 8 and 9 are also omitted, probably because the preacher wants to reach verse 11 quickly. The latter is used all through the sermon as a type of maxim for the Afrikaners' situation. The preacher's text combination now fits this situation. In fact, the preacher designs a text combination and a shift of emphasis to fit the Afrikaner situation perfectly, in order to provide scriptural sanction for this situation.

Two revealing understandings of time permeate the sermon. Firstly, the preacher states that these events took place during the Babylonian exile under Nebuchadnezzar, during which the Jews lived in most dire circumstances. Then the second time indication and the analogy follow:



The fact that the preacher equates the prophet's situation with that of the Afrikaner people leads to further adaptations in the "application" of the biblical text. Two examples illustrate this tendency that appears throughout the whole sermon.

First, a subtle one: "Where we now in the Spirit, together with the prophet, had a view on the valley of skeletons ..." means, for example: we have seen what Ezekiel had seen. The passive experience of the prophet in this ("he leads me out"), 
however, becomes an active continuation of the vision: ("we now wish to try"), etc.

A second, anything but subtle, parallel strengthens the direct connection between Israel's bones and those of the Afrikaner nation:

"Just like Jacob in ancient times went to meet his brother, Esau, but not before he first wrestled with his God .... Exactly so, Blood River is the place where the Voortrekkers personally met their God through the Covenant. It was at Blood River, by taking the Oath of the Covenant, where the Afrikaner nation attained its intimate exclusive Afrikaner-centric final acceptance of being God's blessed people.

The purpose of this parallelization is clear, namely to strengthen and stabilize the "Afrikaner people's" identity. This is especially clear where the preacher extends verse 14 with a phrase from verse 10 ("a vast army") to create the shift to the following paragraph, where we hear: "This is the army of 470 men under the leadership of Andries Pretorius...."

The whole implementation of the text and analogizing serves the construction of the identity of the nation, and wants to raise the people up again. Ezekiel 37:14 becomes a type of salvation prophecy for the "Afrikaner people."

This analogy has decisive consequences for the sermon's God image. The Spirit does not emanate from the Father and the Son, but from a historical date for Afrikaners, from the brutum factum of Blood River. This is where the Spirit entered the body of the nation and aroused them to be God's people. This happened "through the Covenant," which ultimately takes the place of the Gospel of justification. The Covenant declares that the people are justified before God.

However, the analogical schematism not only lacks a biblical horizon, but also makes God manipulable: a particular, fixed image of Him can now be proclaimed. This is a form of lovelessness for the congregation and betrayal of the reality (Frisch, as cited by Marti 1976:173). However, in a situation of threat such an image is useful. It can easily be displayed, easily be memorized to counteract 
anxiety. It is also typically human in situations of anxiety, not to cling to God, but to hold God in your grasp, to revert to manageable, familiar images of God.

Such images attempt to remove God's power, appropriate this power for themselves, and project themselves onto the situation. Speaking theologically and homiletically, this is fatal. Images have the nature of ostensibly merely appearing manipulable. Ultimately, images manipulate us. ${ }^{13}$ We are bound through them and it is difficult to escape from them. On the one hand, we shelter behind images against reality, and they cover our activities and obligations to history (cf. Chapter 4). On the other hand, they dominate us. They do not liberate us, but enslave us with strict imperatives (cf. Chapter 3). We shelter behind images against history and history making, against a change of existing realities, and we are so swallowed up that we can no longer change these realities. We imprison God and we ourselves are imprisoned; simultaneously we are creators and creations of our images; fixators and fixated. We no longer see the reality. In our blindness we transform metaphors into ontological untouchables, we promote our temporary events to become eternal truths and mould our time into statues. Thus we turn God into an object, a thing, and He, the Living, becomes monumentalized for, and in, our interests. In fact, our images supersede and replace Him.

This becomes clear in a sermon based on Psalm 56:4. A few citations:

Day of the Covenant - 16 December - aims to emphasize one great truth for us, namely the power and necessity for true faith in God!

This faith in God was the secret of our forefathers, and without that characteristic, grace and power in their lives, they could not vindicate and cultivate a Christian nation.

The battle of 16 December and the Covenant at Danskraal, which preceded it and through which we, as a nation, are bound, emanated from this faith in God of the Voortrekkers ....

\footnotetext{
${ }^{13}$ Linguistically speaking, this is true. On the one hand, language is the medium through which relations of power are maintained; on the other hand, language is, indeed, formed and controlled by power relations. In other words: language exercises power to create images, but images exercise power to create the language! (cf. Kress \& Hodge 1979:103ff).
} 
Thus, to celebrate the Day of the Covenant does not entail boasting about people and their deeds of heroism. We are called to note the fact that, when they feared, they trusted in God, and that they were victorious in, and through, their trust in God. In this, we shall also come into a correct relation with our God and our trust in God will become firm and strong.

However, the Word of God also calls us to give an account of our actions today....

The Day of the Covenant appeals to us to confess our sins and to acknowledge Jesus Christ as Lord and Saviour. We must link our predestination to God our Father and restore our trust in God....

But, 16 December appeals to us also to look forward to the future!"

It is significant that the Day of the Covenant attains a metaphysical quality. In the first sentence the Day of the Covenant becomes hypostatized; it becomes a person with a will when the preacher says: "the Day of the Covenant aims to ...." Later, in an impersonal construction, we hear: "We are called...," which actually means: "The Day of the Covenant calls us." ${ }^{14}$ But, more important, by our noting the Voortrekkers' trust in God, "we shall also come into a correct relation with our God...." The Day of the Covenant becomes a mediator between God and ourselves; those who do not keep the Day of the Covenant, are not in a correct relation with God. In fact, the preacher continues, “...the Covenant appeals to us to confess our sins and to acknowledge Jesus Christ as Lord and Saviour" - this

\footnotetext{
${ }^{14}$ Kress \& Hodge (1979:72ff) illustrate convincingly how passivating, nominalization and similar transformations have an ideological function. Transformations, according to them, are processes through which elements present in deeper structures are deleted, combined and rearranged in superficial structures, so that the latter can only be interpreted by a reconstruction of the deeper structures. Nominalization takes place when sentences, or parts of sentences, change the descriptions or actions and participators in them into nouns. The effect is to blunt the feeling of activity, to eliminate the complicity in actions and to transform processes into objects. Passivating - to use verbs in the passive form - involves also the elimination and disguising of the main agents and focuses the attention of the audience or reader on certain themes to the detriment of others.
} 
the Holy Spirit does normally. So the Day of the Covenant also appeals to us to "look forward to the future," and, squeezed in between the appealing voices of the Day of the Covenant, the "Word of God" also appeals to us with a view to the present. The working of, significantly, the first words of the sermon: "Day of the Covenant" colours the whole sermon.

The use of the words "trust in God" is interesting. As the second key phrase, it dominates the sermon. At first, it is called a "secret," but then a "characteristic" and "power," and in between "grace" - as though the preacher wants to qualify what he is saying. In fact, he says that the Day of the Covenant is not about "boasting about people and their deeds of heroism," but, on the contrary, that the battle of 16 December "emanated" from trust in God. In addition, our trust in God becomes "firm and strong" through celebrating the Day of the Covenant. In other words, we already have this potentially, but it must be "restored", and this takes place if we "link" our predestination to God. Apparently, there is a tradition of trust in God that links the generations to each other as a national biological fact, which is a characteristic of the nation. Viewed rhetorically, the reference to predestination is a classical example of "blurring the issue": it sounds familiar and correct, but it means nothing, because who are the "we"; what is the predestination and how do we link with it? This is a rhetorical cloak to conceal the actual agent in the sermon and to sanction its performance, namely that of the nation. Such generalities fit any text. However, the question we should ask is whether such texts also fit these generalities and whether their specifics could be articulated within these generalities. Generalities are in opposition to the Gospel, which always has a specific word for specific people (Bohren 1974:408).

In any case, in the sermon the inherent trust in God becomes a condition for God's faithfulness: to the extent to which the nation exercises trust in God, $\mathrm{He}$ demonstrates his faithfulness. The national history becomes salvific history through the nation's trust in God. Here, the doctrine of justification is not so much that of the godless who are justified through faith, but the birth and identity of a nation that is made possible through trust in God. The good work of trusting in God is rewarded with national stability. As in all of these sermons, the background is the anxiety-ridden situation of the "nation." This already is evident in the first sentence ("necessity") and, in fact, the preacher explicitly spells this out 
in the rest of the sermon, and uses it as an impressive rhetorical technique to persuade the nation to adhere to what the tradition (of the Day of the Covenant) dictates. In this way, trust in God must be maintained in the midst of all anxiousness.

The formation of images ousts God and creates a vacuum. Then, the image itself enters this vacuum as a surrogate for the living God, and, in this way, attains the image of a specific kind of myth (for extensive discussion of this process, cf. Slök 1960:1263ff). This phenomenon is complex by nature and, for example, can be described in philosophical, philosophic-semiotic, sociological and religioscientific viewpoints. In formal terms the myth is a narrative. Yet it is to be distinguished from fables, fairy tales and legends that play roles in their own worlds and conclude according to their own rules (until "all live happily ever after") and especially function with their own concept of time ("Once, long, long ago ..."). Indeed, myths do have their "own" times that transcend the boundaries of history, for example, in the so-called anthropogenic myths, in which the world's "ancient history" is told, or the cosmogonist myths, in which the "prehistory" of the world is at issue, and certain personal myths, in which either unhistorical or historical figures act and who start to display unhistorical, timeless traits in the narrative. Yet, the myth often enters into a relationship with "real" time. For example, in a cult the myth is retold and celebrated in order to continue it. In the cultic repetition the myth attains "eternal" value and, in this sense, it is an allegory (image) that verbalizes the "eternal" in human words. Thus, the myth moves from the "eternal" into time to again become "eternal." Myths use time (cult) to keep themselves alive.

In any society myths play an important role. Strictly speaking, it is impossible to live without myths (images of reality). They can make life more bearable. In the sociological sense myth making is a legitimating system for human relations, a system that not necessarily is negative. These systems form a medium for collective experience, which determines how people view, organize and understand life. They remove the tension and risk of individual choices. On the one hand, they offer possibilities for identification but, on the other hand, they diminish the playing-fields of freedom and become closed systems (Cancik 1970:19). Hopewell (1987:46-51) points out that congregations also function in 
terms of collective narratives, that they express the congregations' self-perception and inner communication and enable participation in society's greater narrative structures. In latching onto the classic categories of Northrop Frey, Hopewell (1987:58-62) distinguishes between romantic, tragic, ironic and comical narrative genres to express the intrinsic patterns of action, the vision, the story of specific congregations and theological traditions. In fact, each congregation or theology, whether aware or unaware of this, functions according to such a story! Thus, it is a communal story that, explicitly or implicitly, reflects and forms important aspects of a congregation's philosophy and ethos (or, even broader, of a society), and elicits powerful emotional responses.

On the one hand, they function descriptively, in the sense that they describe the collective living world, the "symbolic universum" of a group and, on the other hand, prescriptively by appealing for concrete deeds and attitudes in order to maintain the myth (Adonis/Smit 1991:4). In this process there are a number of "fixed points," such as revelatory traditions, heroes, etc., that cause the myths to offer a type of "objective security" (Cancik 1970:18), a safe and familiar world within which the members of the group can flourish.

However, a myth also has the potential to be destructive and self-destructive. It can endow certain matters (truths, half truths, untruths) with ontological authority, sanctify them and make them unassailable; they can make society not more bearable, but inhuman and even destroy it. A myth can perpetuate social injustice as archetypical eternal orders (Croatto 1983:41). From history this appears especially to be the case with religious myths, where the myth gradually starts adopting the role and function of the Word of God, of the Gospel itself, but then so that it functions unilaterally and with authoritarianism, and with feigned godly sanction (1983:43). Thus, while it is simplistic to contrast myth and truth from the start, it also is a fact that ideologies are interwoven with myths (1983:30). They demand fine scrutiny and ideological criticism, in which the choice is not between myth and non-myth, but between various types of myths, either edifying or destructive. In this respect, Grabner-Haider (1989:290) appeals for the humanizing of myths and religion by guarding against the inadequate and destructive elements of myths, i.e. their ideological traits. 
In this research I follow the classic findings of Roland Barthes (1964:110ff) regarding the philosophy of language in connection with myths. He researched, linguistically, the creation and the development of common myths and came to the conclusion that this type of myth interprets and relates history in a way that is fundamentally different from historical science in writing history. While the ideal of the latter is the understanding of history in all its facets, myths change history into nature (1964:113). A few viewpoints are abstracted from the unique interrelation of historical events and changed into a repeatable pattern. This pattern or principle is applied with a specific objective, for example, the justification of social, political or ideological structures. In fact, myth is richly chequered and can serve any common, human needs and actions.

According to Barthes, the essence of a myth exists in its love of, and continuous search for, timelessness. Real history is negated, annulled and changed into a myth. ${ }^{15}$ To be timeless, the myth thus uses history and never becomes altogether detached from it. It also does not want to do so, because it lives on it, finds its roots in it, and especially conceals itself in it. According to Barthes (1964:97ff), this secretive game of hide and seek defines the nature of myth.

The analogical scheme, which also wants to create a timeless system, is a form of myth building. One of the components of myth building, indeed, is to make a law, a principle, from two specific non-interchangeable times, and thus escapes from history. In this case, the biblical, as well as Christ's, history also disappears (cf. Chapter 3) and is so betrayed that it is at variance with reality. Because real history is replaced by the myth, biblical history is no longer a unique event and one day of the Lord, nor is the contemporary situation, which preachers want to justify, a unique event, a new day of the Lord. No day of the Lord comes to fruition, because the myth defines it away and eliminates it by means of analogical schematism. The myth lives on this timeless "nor...nor", it is a tertium non datur, a third power alien to reality. It is not a real history, but an intellectual history, because it has an intellectual birth, contrived and moulded by humans.

${ }^{15}$ Contrary to this, one could argue that historical categories of causality are only extensions of the antique myth (cf. Naude 1963:33ff). In my opinion, what could indeed be said is that historical concepts of causality reduce complex data to rational categories and, in this sense, change them into a new premise. 
This "history," this myth, is the nation's history as reflected in the sermons and in which the people's identity can be found. The purpose is that the national history must attain eternal, unchangeable value. This takes place through an "exchange" and identification of histories: ${ }^{16}$ the salvific history is replaced by the nation's history, and vice versa. The history of the people becomes divine, becomes a revelation - of the myth. In the process God is not only dehistoricized, but $\mathrm{He}$ also becomes historicized nationally in the sense that he must legitimize the national history. This exchange of histories is possible - in Barthes's term (1964:113ff) - because the myth changes history into nature, because it brings to the fore and absolutizes timeless, generally valid, stringent aspects of history by means of abstracting, reduction and analogies.

In the analysed sermons this distinctive "salvific" history of the people is told and retold, virtually without exception. It forms the unassailable fixed point of departure and assumption. On the one hand, this is done to remind the "nation" of its past. On the other hand, it must serve as an impetus with the view to the future. However, its most important function is to serve as apology, as justificatio populi in a time of threat and anxiety. It forms the frame of reference and anchor for stabilizing the current national identity. From this national historical foundation, it also wants to say: God is for us.

A telling example is a sermon on Psalm 62:6. It starts with a national-historical view on Psalm 62:6, which forms a type of framework within which the sermon explains the text and has a strong suggestive power: the text now also has important things to say to the Afrikaner people. It proclaims certain national historical events (1961; birth of a Republic) as divine revelation, a "direct result" of the prayers and surrender of the forefathers in 1902. In eschatological terms, the sermon refers to "the liberated", who "one day, from every race, and language and people and nation will sing the new song in the kingdom of the glory," but this reference is not only out of place with the rest of the sermon, but also is the

\footnotetext{
${ }^{16}$ Since the 1930s and 1940s this tendency was quite explicit in some sermons. Many elements of the way of preaching that we research here naturally can be found in preceding decades. A single example - as deterrent! - "If we listen to the songs of praise that rise above the domes of churches and the roofs of halls, then it is as though we hear the voices of two that call: the voice of God and the voice of South Africa" (Boshoff 1959:10).
} 
often used rhetorical technique of blurring the issue, of softening the real argument. The preacher in fact wants to intensify the focus on one "nation", not many. Therefore, he emphasizes that this nation must look "past" the noise of (other) nations; that the Roman Catholic Portuguese and Spaniards sailed "past" the Cape of Storms, while the pious forefathers landed here, and that the nation must "look away" from the humiliation and threat presented by the economy, allies, weapons and warmongers. On the one hand, the national history then becomes the source of appeal to bring order to the national house. On the other hand, the faithful waiting and the stance of the pious people forms the condition that God will again act in the present and will "ensure" the people's future existence. God becomes the great Guarantor of the nation's future existence, but on a condition: God, who created the people out of grace, will only allow them to exist in future if they act according to certain ideals. God's actions depend on the inner condition of the national soul: "If a nation's heart is right, then its future is safe." Like a refrain, the conditional sentences sound: "If ... then ... is ..." (cf. Chapter 3 on the function of conditional sentences).

The closing paragraphs of the sermon elaborate these ideas further and read as follows:

"In these hours of crisis in their existence, the nation of South Africa must expect much from God. We must not have our view obstructed by powerful enemies, but must focus on the Almighty. We must have great expectations of God and must be alive in faith.

"And, on the road of South Africa, there are beacons of light as symbols of glorious victory, because our people expected everything of God.

"In an alien, wild country, at the beginning of the people's settlement, Jan van Riebeeck brought a dark Africa before God in prayer, and Africa opened up for the Gospel and civilization.

"Farmers moved into a cruel and wild country where predators and barbarians were a dangerous threat, but, in lonely farmhouses, the Word of the Lord saved a nation from being frightened away. 
"In very dark moments - Vegkop, Marico, Blood River - a small nation just trusted in God, and, for God, a small minority was a majority.

"In their struggle for freedom, a courageous nation lost, but, in their defeat, they became silent before God and placed their expectation only on Him. A free, united nation grew from the remaining stump. "And now again, the people of South Africa must expect much from God. Our Father never gives his children a stone when they ask for bread. 'Seek the kingdom of God and his justice and all these things will also be given to you.'

"In prayer and witnessing about the Lord, expect a renewal of his church.

"Pray that the Word of God will be proclaimed with power and that our people will act righteously, will consider love and walk humbly with God.

"Then the Lord will be our shield and fortress in the struggle.

"Then a beautiful future will be our destiny and our people will also be able to provide leadership in the world.

"We must expect also this from the Lord - that when the hour comes for our nation to provide leadership - and it will come; that we will then provide leadership according to the guidance of the great Leader who leads all things to a triumphant end.

"The God of heaven will make us happy, and we, his servants, will prepare and build.

"Just be quiet before God, my soul, because my expectation is on Him - Amen."

The first paragraph begins with an exclusive claim, namely that there is no other "nation of South Africa" except the Afrikaner nation, followed by the imperative 
flowing from the national history (on this, cf. also Chapter 3) emphasized by the use of "must" no fewer than five times. For this, the "beacons of light" on "the road of South Africa" offer encouragement. Even more important: the nation's historical performance becomes the most profound basis and reason for the glorious victories in South Africa: because this "small nation just trusted in God." The nation's history itself becomes the source of the revelation ("beacons of light"), becomes revelatory history; it operates as the norma normata according to which South African history, and eventually also the future, is to be judged. The point of departure is this: previously, the whole nation was for God, therefore God was for the whole nation. The people's actions ensured their triumph. This is spelled out with the assistance of four reminders of the forefathers' performance, and described in such legendary and idyllic terms that the fathers become dehumanized, people without shadows, a great crowd of national witnesses, as it were, who must inspire the present generation. Jan van Riebeeck breaks open a "dark Africa" with his prayer "for the Gospel and civilization." The "Word of the Lord" saves the trekking farmers exclusively "in lonely farm houses ... from being frightened away," and they stand in strong contrast to the "hard and wild land" and the threat of the combination(!) of "predator and barbarian." Despite the country being wild, the nation is saved from being frightened away. Dark moments of the national history ("Vegkop, Marico, Blood River") are lined up and the national idyll repeated: not only did the nation expect "everything" of God, but also "trusted only in God." Their dedication was complete; therefore they again placed their expectation "only" on God after their defeat in the freedom struggle. This expectation caused their so impressive growth that the preacher can validate it with a prophetic word: "A free, united nation grew from the remaining stump" (cf. Isa 11:1).

On the basis of this national legend, the "people of South Africa" must again expect much of God. As an ethnic body, the people must, "In prayer and witnessing about the Lord, expect a renewal of his church"; the people's prayer and witness must allow the church to relive. This is possible because the people are "children" of "our Father." The people's prayer is the condition for the Lord to ensure the future, that He will be the "shield and fortress in the struggle" against other nations (with emphasis on: "Then ... then ..."). This is also the 
condition for the nation to "provide leadership in the world." Here the idyll reaches its apex; it becomes a fantasy of omnipotence: the nation definitely will be the world leader ("and it will come"). For this, he needs a triumphant example, whom the preacher does not name ("the great Leader"), but he implies it is Christ. Christ becomes the example for the nation on the basis of the piety of the nation, and with the view to the consolidation of this piety.

If I have understood it correctly, this sermon does not so much interpret the Bible text (Ps 62:6) and respectively proclaim the Gospel to the congregation, but proclaims the national history as legend and ideal to the people. This forms the actual text, and actual gospel of the sermon.

It is clear that this myth of the national history has a decisive influence on the structure of the sermons and, indeed, in this respect it exercises great power to perpetuate relations of domination (see Chapter 1). After all, this is not something that started yesterday or the day before, but grew in the South African theological tradition and way of preaching. Yet the paradox of this is that it remains within the realms of unreality. As national pastoral rhetoric, it lives on (elements of) reality, to act against reality, and to escape from reality. It usurps and equates itself with biblical history, especially the history of Israel and, using that as an incessant guide, implements this to keep itself intact. The relation between Israel's history and the mythological history is that of example and image: Israel is taken from its unique revelatory context, starts functioning homiletically by itself, and thus becomes the storehouse for imagery. In the process, it becomes homiletically counterproductive, hampering the open view on the biblical as well as the contemporary South African reality; and it does not allow a prophetical insight, perspective and outlook. The courage to face this reality and the freedom to confront it, therefore is obstructed.

The mechanism - we could say the theological tool - with which the myth opens the entrance to invade and destroy reality is analogical schematism. In fact, in the sermons it is characteristic of this myth that, in essence, it is concomitant with an analogical schematism. The one does not exist without the other. The myth reproduces itself via the analogical schematism. To be able to do this, before any change dare take place and as a deterrent against transformation, it must always reproduce the status quo, or rather the status quo ante. Different to other critical 
myths, for example, in Marxism, this myth is a national myth that is vigilant over the nation's self-preservation and self-justification. Therefore, it is against change in principle. It functions like a pre-judgement against all signs of it; it is intolerant of all other historical images. For itself, it demands an explanatory monopoly of history and turns preachers into opinion monopolists. After all, it tells the national history before the actual history has taken place; it already knows everything in advance.

In its most profound core, this myth has a conservative structure. After all, it allows time, as mythical time, to freeze. The point of departure is that yesterday's world (or in this case, yesterday's unreal world) has the monopoly on what is right, and that this right -God Himself - is preserved therein. From the start, any opposition, or even dialogue about it, is excluded. The myth offers a code for preservation. Its stereotypical components form the code's secret writing that must invoke immediate and predictable reactions in those programmed. It wants to keep the control, keep producing the manual, the instructions for use, as the myth requires, when the world goes to rack and ruin. It forms a refined weapon in a bitter struggle to exist, in a situation which rather requires prophecy. Simultaneously, it is an action driven by necessity, born of anxiety, but also has the strategy of a law holder and enforcer, an anathema and exhortation to disempower the opposition and to keep the threatened order intact. It always views itself as the only security, as the exclusive condition for life to be realised amidst change. It always offers itself as a secure stronghold, despite crumbling foundations.

The tragedy of this myth is that it is self-destructive, in contrast to other myths that are self-propagating. From the sermons it appears that this powerful myth has been shaken in its foundations, that it has begun to lose its historical power, despite the fact that all was being done to spread its spirit (illusion!) in South Africa. The reality starts to punish the unreality; the cranial, intellectual history starts bumping and breaking this cranium against the reality. Why? Because the myth not only arms against all that is "outside," but also corrodes internally, because it is doomed to self-destruction by its ultimate self-isolation and loss of realism; because people participate more in this reality, are more part of this reality than what the myth wants to and may allow.... 
The connection between the myth and the apocalyptic mentality dominant in the sermons is significant. Myths function differently in times of peace and quiet than in times of national crisis (cf. Hanson 1983:13ff). The growing panic at social, political and economic level, and the naked fear of imminent total extinction, sometimes causes myths which were dormant and obscured under the surface for many years suddenly to become aggressive, to fiercely form a lager against what is regarded as a threat to the foundation of life. Essentially, this myth is a survival strategy according to old recipes, a strategy which, historically speaking, had a certain effect and offered a certain security. Now, this is applied to the present and must also ensure the future. Towards this purpose the myth rallies all its power - regardless of the cost and no matter how few the supporters. 


\section{THE SECOND HERMENEUTICAL STEP: INWARDS, INTO THE POTENTIAL OF THE “PEOPLE'S” SOUL}

In the process of building a myth, analogical schematism uses a number of mechanisms that are usually reliable signs and consistently accompany schematism, and belong to the essence of the myth. For example, the analogical schematism is continuously articulated in imperative speech structures. Between analogical schematism, myth and these speech structures there is a logical and assessable connection. In fact, the analogical schematism as such already embodies and therefore provides the imperative structure. The actions or situations of people, who, in biblical times, formed the presumption for the proclamation, today become conditional for the content of the proclamation to be activated again (Josuttis 1966:24). What previously was a word about God's actions in history becomes a word about people's actions in history, and in such a way that it forms an appeal to the present audience to act accordingly. Theological declarations become moralistic appeals; given situations (in which God acts) become conditional situations (in which people must act), for example:



"For us the transition from the old to the new year must also mean what Ahawa meant for Esra and his co-travellers."

"Like Nehemia, every father and mother, every young person and child, every national leader and educator, every preceptor and preacher must feel God's hand on him."

The analogical schematism first projects a false image on the reality, and then it appeals for the maintenance of this image. The image forms the norma normans 
for action and the image demands action in accordance with the descriptive and prescriptive nature of the myth (Chapter 2). Therefore, it is quite understandable that the analogical schematism mainly appears in conjunctive speech forms: realities are discussed as possibilities; instead of realities, possibilities are postulated in the grammatical form of the conjunctivus irrealis. However, these postulations are also subject to a condition: when people perform certain actions, it will be evident that the mythological postulated and unreal image of history can become a "reality," that it is "true" and "normative"; the current time will then indeed be akin to past times, and vice versa. Therefore, the conjunctivus irrealis becomes visible in the conditional construction of sentences, even when it does not function in this way explicitly, as in "when ... then," "if ... then," etc. In this way salvific historical realities, the reality of God Himself, are discussed. Because God is incorporated into the postulated image of history, He is also discussed in unreal, conditional terms (Bohren 1991:3).

As an illustration, I refer back to the sermon based on Nehemiah 4:14 (see Chapter 2). The analogical schematism brought the preacher to the point where he asks whether history will repeat itself. Should this be the case, as indicated, God is taken out of history by implication, and He is made unreal. The conclusion of the sermon can, indeed, be understood in this way. I quote a few core paragraphs:

"But then 2500 years ago, a word of God fell into the heart of a man and when this man communicated this word to his people, then the scene changes because people have changed."

"But, do we think enough of 'the great and formidable God'? Is his omnipotence still an experienced reality for us?

"Does the message, the work and the results of the church still stand in the sign of the powerful wind of the Holy Spirit, the wind that blows where it will and which cannot be stopped by any human power or science? 
"Like Peter, do we look at the waves resulting in the depths swallowing us, or do we look at the Finisher of our faith, who demolishes mountains and dries up oceans?"

"O, if God only again could attain a first place in our thoughts, our judgements and our actions, then the church will be able to do something awesome to, and for, this world.

"Yes, then the rest of Nehemiah's commands will also be executed. Then we shall be able to 'fight for our brothers, our sons and our daughters, our wives and our houses."

"When Nehemia spoke about a struggle concerning the lives of sons and daughters, wives and houses, there was no despondency in his heart, because, in the same breath, he could say: think about 'the great and formidable God."

"But when I receive the grace and the enlightenment of the Holy Spirit to think above all of the great and formidable Lord, then I hear the King of the church also saying to me: 'For God nothing is impossible.' 'Not through power or violence, but through my Spirit, says the Lord of hosts.'

"Then the church can answer with a joyful heart: 'Who are you, great mountain? Before Serubabel (before the Church of Jesus Christ) you will become demolished!"

With these paragraphs, the preacher wants to build a bridge from the biblical history to the congregation's present situation. Therefore, the first sentence starts with the present tense: a word "falls" and there is a man who "communicates" it. This is followed - still in the first sentence - by the past tense: the scene changes "because the people have changed." The preacher has exactly this in view: that the 
audience - people who live in critical times - will change, like the people changed in the olden days. The past and the present, after all, must overlap. But how?

The following paragraphs consist of a series of rhetorical questions ${ }^{17}$ concerning the position of the congregation and the church, yet they do not say how the change can take place. The questions imply: the things that are questioned are not so; the answer to all is: No. Therefore, people must change and make it true change the No into a Yes. This is brought to a head in the following key sentence, in which not only the circumstances, but also God's position in the circumstances, is conditional on human action: "O, if only God again could attain such a first place, then ...." Here God is not articulated as a reality, but a possibility, a possibility that is conditional: God only gets a first place, if we have changed. The same conditional, unreal construction applies in respect of the "grace and enlightenment of the Holy Spirit."

When people have changed, then they will not sink down into "depths" (here Peter serves as a negative example), but they rather rise and do "something awesome" to, and for, the world. Nehemiah is presented as a good example; he moved from depths to peaks because he did not have "despondency" in his heart. Therefore, people who must change, must take note of this person who changed, they must look into his heart, into his soul, and so learn not to lose hope. This psychologizing of Nehemiah then serves the imperative. The closing conditional sentences of the sermon ("When ... then ... and then ....") sends the congregation away with the assignment: please change, so that this "when" can be now, so that God can get the first place in your lives and you can experience the grace and enlightenment of the Holy Spirit.

The sermon's strong imperative character brings to the fore the problem of the relation between the law and the Gospel. This relation is complex and cannot be dealt with here in all its facets. Luther calls the correct distinction between law and Gospel the highest art and wisdom of the Christian faith (summa ars et sapienta christianorum)! This distinction applies especially to the nature of true

\footnotetext{
17 Although one should obviously not generalize, questions of this nature are, according to Josuttis (1996:20), often a sign of legalistic speech.
} 
preaching. To distinguish between the Gospel and the law means becoming a preacher. One can only preach this relation (Iwand 1964:13).

Manfred Josuttis (1966:118ff) studied legalism incisively in post-war German preaching and concluded that there were so few evangelical ${ }^{18}$ sermons, exactly because there was not a clear distinction between the law and the Gospel. According to him, those who want to preach evangelically learn to distinguish the Gospel clearly from the law, because the evangelical aspect of the Gospel exists in its distinction from the law. However, those who understand the Gospel also learn to preach the law afresh, because the evangelical aspect of the Gospel liberates God's law from legalism, from people's misuse of the good law. The distinction between the law and the Gospel thus also provides the distinction between the law and legalism; the first brings the second to the light. Legalism is an irresponsible combination or mixture of the law and the Gospel upon which the ideologization of the Gospel and moralization of the law then follow (1966:13).

This combination can adopt a variety of forms. For example, the weight can lie on the side of the law - then the positive functions of the law (the so-called triplex usus legis) are separated from the indicative of the Gospel; the law attains a legalistic tint. Or, the weight is placed on the side of the Gospel, its pro nobis nature must make room for the demands that people must fulfil; the Gospel is misconceived legalistically. The essence of all forms of legalism is the separation between God and humans, between his Word and our words, between heaven and earth (Bohren 1991:3). The absent God must be "presented" as present. In these sermons this entails that rhetoric becomes an independent force, contrary to theology; that the preacher must do with words what only God can do. However, because this is not based on salvific realities, but on unfulfilled conditions, it imparts the character of the subjunctivus irrealis to the modus of this preaching, not the praesentia realis dei. ${ }^{19}$

\footnotetext{
18 This has become a loaded term, often used by different authors to denote different viewpoints. It is used here in the context of the relation between law and gospel, that is, as a definition of preaching that articulates the gospel in the Protestant sense of the word.

${ }_{19}$ Bohren's whole homiletics could in a sense be understood from the perspective of the presence of God. He writes extensively about this in his Predigtlehre 1974, Chapters 17 to 20.
} 
Also, the distance between the tenses (past, present, future; cf. Chapter 2) must be bridged in this way. Humans remain in the present time under a locked heaven with only themselves to look to. Because this is what legalistic preaching does: it turns people inwards, bending them into themselves. In this respect, the preacher probably is the most bent and the loneliest of all. $\mathrm{He}^{20}$ must encourage the congregation, but he himself is despondent. Because the Gospel must make place for human action, because there is no exoneration proclaimed and therefore acted out in the speech structures of the sermon, the preacher's encouragement is false and his reasoning is empty. God once walked on earth; now only his footprints and the demands for following in his footprints are discussed. The point of departure, most profoundly, of legalistic preaching is God's absence. In this sense, speaking theologically, nothing happens in these sermons: the congregation is informed about what happened in biblical times, which however does not happen today and what the congregation now must do to allow it to happen again (Josuttis 1966:30). A legalistic sermon is without reality, without God's reality and God's working. Because this reality and work are not expressed, an escape route is taken by the proclamation of a legalistic law, a legalistic Gospel, and all possible shades in between. So, the Name of God (his presence) becomes a sucked-out egg, a shell without content. The Name loses its being (Bohren 1991:3).

This of course does not mean that the Gospel as such does not appeal for action, for the response of obedience. On the contrary. However, evangelical ethics is never conditional and is never based on unreality. It is based on salvific realities in the Gospel, which are not conditional. The Gospel does not demand, but gives. It precedes all human actions. Only in this way does the law attain its positive and life-giving meaning: that it is not conceived as a demand, as a naked command that humans must obey from their own reserves, but as a liberating empowerment for daily life from the Word of God. God commands by his giving; God also gives by his command (Josuttis 1966:20ff). Because God gives to us what He asks of us, He can ask of us whatever He wishes (Augustine). We are put to work, but the task is undertaken at God's initiative. Between God and us a theonomous reciprocity develops, an interaction, which is permeated from beginning to end through the grace of God (cf. Bohren 1974:76ff).

\footnotetext{
${ }^{20}$ In this case, exclusive language must be used. All of these sermons were preached by men.
} 
In my opinion, this integrated interaction is broken principally in these national sermons. While there is an abundance of national appeals, the lack of speech structures that articulate the free grace of God is significant. ${ }^{21}$ The nation's threatened situation apparently makes the arch-temptation to exchange the Gospel for a legalistic law even more irresistible, and especially to exchange it for a legalistic Gospel, as the analyses indicate. The Gospel itself is affected in its heart, in its very essence. Its "weakness" apparently does not offer solutions for a situation that requires drive and action; therefore, a law is grabbed that makes things more manipulable and viable. In this way anxiety must be countered. After all, it appears to be more "logical," and offers more "handles" in difficult times.

We must try and understand this. This type of sermon is based mostly on the Old Testament, where faith is accepted as obvious because all are "of Israel," and a particular covenantal metaphor of conditionality functions strongly - especially in the Deuteronomistic texts and Jerusalem's theology. Those who do not interpret the Old Testament theologically fall prey easily to equating a nation (here, the Afrikaner) with Israel and thus forming a type of civil national religion (cf. Deist 1990:124-137).

In fact, the majority of sermons start with a perverted type of ethics (in the sense of a political threat to the national ethos) instead of theologically. The whole structure of the sermon is determined thereby and normally illustrates the dramatic wrestling of the preacher to offer theological (but in effect: legalistic) answers to the questions that are raised by the national ethical point of departure and, paradoxically, it indeed illustrates the preacher's battle to escape from legalism.

${ }^{21}$ Research done on tendencies in Afrikaans religious programmes (Müller 1987:44-46) indicates an interesting parallel: the religion that is offered for general Afrikaans-speaking people is almost always imperative in nature, but then not as an appeal that affects the daily and concrete reality. It rather is a type of alien-to-life, non-existential appeal - a type of mythological demand! The programmes' contents say virtually nothing about the objective extra nos of salvation and faith upon which the Reformists placed so much emphasis. 
In the sermons stereotyped national ethical situation analyses, ${ }^{22}$ which often form the introduction to the sermons (cf. also Chapter 4), offer the background against which appeals to the nation are made and, in this sense, function as a motivation for legalistic declarations, such as the following:

"Become more inspired every day and show more enthusiasm every moment for eternal and unseen things .... Allow a divine power to flow from you into society and the world in which you live."

The preacher means well, but is heartless. An absolute demand confronts the congregation ("become more inspired every day and ... more enthusiasm every moment ... divine power"). Nowhere in the sermon is this imbedded in the theological context and promises of the gospel. Rather, the congregation is left alone with the impossible: "Become more inspired ... Allow ... flow from you." This might qualify as a motivational speech, but, in my opinion, not as the Gospel!

"The question that comes to us, as individuals and as a nation, is: Do we still possess the trust in God that was so characteristic of the Voortrekkers and that was the secret of their way of life that reflected strength of character, their unconquerable spirit? Do we still know the God of our fathers? Do we still know the infallible promises of his Word?"

In this case the listener (typically, not the congregation, but "individuals and ... nation") is left alone with a law that emanates from the ideal image of "strength of character" and "unconquerable" national heroes. However, there are few things that are as intolerable as the dumb command of a good example (Mark Twain). In the light of the "good example," the audience is confronted with a question and turned into themselves. National heroes become the law. I repeat: this is not the Gospel!

\footnotetext{
${ }^{22}$ Naturally, situation analyses can be used positively in sermons and form the background against which the Gospel is unlocked. However, experience has taught that this often is not the case (cf. in this connection Josuttis 1966:33ff).
} 


\begin{abstract}
"In our history there were people with names such as Sarel Cilliers, Andries Pretorius, Piet Retief, Paul Kruger ... names that stood like rocks. Names of men, who kneeled before God's open Word, took their standpoint and took their vows: We shall stand steadfast; we shall trust; and we shall not allow ourselves to be swallowed up; and to God all the honour!"

"Where are their children and those of others like them today? What is the value of a name ...?"

"Today, the responsibility rests on us not to lose what our ancestors attained with their blood through our weakness of spirit."
\end{abstract}

Again the congregation is confronted with the claims of a national nomos, this time so that national figures attain the same function and status as idealized biblical figures, e.g. Daniel and his three friends. A double imperative, as it were, goes out to the congregation: the exemplary demand of Daniel and his three friends, via Sarel Cilliers and other national heroes, is directed to the congregation. They may not be weak in their spirits; but must rather stand "like a rock." The purpose certainly is, as the political slogan says, to take from history what is good (perfect) and to build the future with it. But I contend again: this is not the Gospel!

All these forms of legalism presume a person with potential, a person who can even undo sin. As the point of departure, legalism takes not only an unreal, absent God, but also a vital, intact person, a homo intactus instead of a homo peccator. In this case, the "national theology" leads to a distorted anthropology and a distorted ecclesiology. It finds its breeding ground in a faulty hamartology (understanding of sin) and a theology of triumph - of the human being (cf. also Chapter 4). In essence, these sermons could be called "liberal": superficially, they seem 
"conservative" and "correct"; however, their more profound basis is not the Gospel, but human beings. Even if this human being is also pious. ${ }^{23}$

A significant example is a sermon on Noah's times and the difficult times that the "nation" experiences. The sermon starts in a stereotypical way - like many sermons from this era:

"It is not news that our national life is being attacked."

Already in this first sentence decisive hermeneutical decisions are made, affecting the rest of the sermon. On the one hand, this implies that the national life is inherently good and guilt is not the cause of the threat. On the other hand, those that lead the "onslaught" are the guilty and, indeed, they are forces of evil. Further in the sermon we hear that the nation is "the prey, the target of the onslaught" [my italics] (cf. in this connection Chapter 4). This is followed by a detailed description of this "onslaught" against "our traditions and morals" and an analogy:

"One gets the impression that our times and circumstances are not very different from those in Noah's time."

This means: those who lead the "onslaught" are like the evil and corrupt people in Noah's time, while the nation is identified with Noah, but then a very specific type of Noah. This, for example, is apparent from the following:

"Against this dark background of a time of sin and unrighteousness, Noah is outstanding. He shows that God, at all times, is prepared to give his blessing to a person who is prepared to walk with Him. Noah shows that a person can remain upright amidst unrighteousness and faithlessness. And, for us, the miracle and encouragement is that God never changes: that He is the same

\footnotetext{
${ }^{23}$ In an investigation into the scriptural exegesis done in the Dutch Reformed Church, Deist (1993; cf. especially Chapter 4) indicates that "unsanctified" reasoning has to a great extent become the basis of this type of theology, a state of affairs that is homiletically confirmed.
} 
yesterday (in Noah's time) and today (in our time) and to eternity (until the end of time)."

The strong emphasis on human potential is again significant. Noah is "outstanding" and proves "that a person can remain upright." In contrast, sin forms a "background" of which Noah is not part. But even more: his remarkable piety becomes the condition for God giving his blessing, because God is "at all times ... prepared to give his blessing to a person who is prepared to walk with Him." God's preparedness is subject to Noah's preparedness. This is also stressed by saying that God always acts thus!

The example of Noah is taken further when the preacher builds a bridge to the present:

"If Noah could do this, then anybody else can do this by the grace of God in Christ Jesus. But we have become weak - people without mettle or deed."

The preacher possibly notices the overemphasis of general human potential in the abovementioned sentences (the presumed human capacities) and tries to relativize this by his reference to grace. Rhetorically speaking, this reference is again a technique of blurring the real argument (cf. also Chapter 2). Who the "anybody else" is here is not mentioned, and especially not how the grace must function - that is, how the "by" must be understood. However, the context clearly indicates that, for the preacher, grace is the result of human action. The technique of blurring, indeed, functions in this way: it seems like A, but actually is B concealed in a rhetorical cloak. Superficially, it seems like the proclamation of grace, but the deeper basis is human, in this case the nation. The reference to grace, in fact, is robbed of its power by a string of semi-palagian sentences, in which humans, with their potential, are at issue again. Admittedly "weak" humans, without "mettle or deed" (cf. "have become ..."), but still humans with the necessary potential to live up to the national ideal. 
This sentiment is clearly heard in the conclusion of the sermon, where the preacher gives the "answer" to the "onslaught on our national life," i.e. where the first sentence of the sermon finds its "solution":

\begin{abstract}
"On the other hand, like the prodigal son, you can take a decision when reading these words. You can decide that if the grace of God was enough for Noah among his contemporaries, then his grace is also enough for you among your contemporaries. You can bow before God and accept his grace in Christ Jesus. You can arrange your home life so that the Word of God holds the central spot. You can remain upright against external onslaughts by arranging your life so that it will be clear to all that you walk with God - Amen."
\end{abstract}

Again, here the "grace" of "God" and "Christ Jesus" are mentioned, but all this is subject to humans who act. Like a refrain it sounds: "You can...."

While the biblical text has a theological content in the most profound sense of the word, and wishes to give insight into God's heart, the sermon interprets it in anthropological categories, and it wants to provide insight into Noah's pious heart. In fact, his figure fulfils a decisive role as example in this sermon. He is the image of the homo intactus, who must be emulated in the analogical schematism (here an anthropological analogue), according to which the nation must model itself in an exemplary fashion. In this sense, he is the false, fixated image of history (see Chapter 2), a person without shadow or stain; even more, he is the fixated image of God Himself. In Noah, God becomes incarnated as homo intactus, so that he takes over the role and place of Christ. Strictly speaking, Christ and the use of his Name in the sermon are unnecessary. Noah is already there. He is the anthropologized image of God, the basis for my possibility to do that for which I have been called. The Name of Christ only forms part of a rhetorical blurring technique, behind which the ideology of a justified nation is concealed, a nation that becomes the norm through which the rest of the world is judged as evil and corrupt. This judgement takes place on the basis of the image of Noah as intact national idol and with the presumption that the nation's "traditions and morals" are inherently good. 
In the light of this anthropologization of Christology, it is understandable that the analysed sermons have difficulty with proclamation as nihil nisi Christus praedicandus. If I have interpreted this correctly, Christ and the message of justification through grace do not fit into the fundamental hermeneutical structure of these sermons. A short-circuit takes place in which the anthropologization of Christology is concomitant with the Christologization of anthropology. The uniqueness of Christ becomes common in humanity: every person becomes a Christ. ${ }^{24}$

As a result of research done concerning German sermons on God's Providence, Rudolf Landau (1981:191) coined the concept, anthroponomous subordination. By this he implied that the dogmatic topos of the concursus Dei or the cooperatio Dei et hominum has to be understood thus in general or, in any case, has to be expressed in words, that God's actions are to be subordinated to the general moral quality of human actions. Humans subordinate God and compel Him to passivity by betraying the Word of justification by grace only in favour of the ecclesiastical homo faber. This ancient guilt of the church is an attempt to undo what God did in Christ in the church and theology. Human work "improves" and replaces Christ's work.

Although there certainly were essential differences between the German sermons and the sermons taken from Die Kerkbode, the tendency to subordinate God occurs in both. Thus, for example, in anthropologizing Christology, both preaching traditions display strong individualistic traits. The embarrassment of the nation's condition apparently does not lead to the discovery or rediscovery of the church in its existence before God, but to a distorted ecclesiology and a sinking back into individualism. Because the nation has declined and can no longer be trusted with the myth, individuals must save the situation.

An example of this individualization is a sermon based on Nehemiah 2:20. The introduction reads as follows:

${ }^{24}$ This should be distinguished from the New Testament perspective of being transformed to become Christ-like (e.g. 2 Cor. 3:18). Luther, for instance, said that we should all be (a) Christ for one another. The difference, however, lies in the basis of these confessions: in the sermons it is a moralistic basis, distorting the theological context within which Christ-likeness should be understood. 
"Those who, in these disrupted times, regard God's Kingdom and their own soul seriously, those who regard our nation and their own house seriously, must undeniably realise that every Christian has a costly calling."

The double "we" of the biblical text ("We are his servants, and we will start rebuilding ...") becomes a double "those who" in the first sentence of the sermon. This "those who" conceals the imperative: the listener must become one of "those who." A series of things which must be taken "seriously" is mentioned and the result is a concentration on the individual: "every Christian" must realise that he or she has a costly calling. This individualization we hear throughout the sermon, for example:

"It behoves everybody, with all the sincerity of his soul to ask himself the question: What kind of builder am I on the spiritual house for which God destined me?"

Here, we have an almost classic model of legalistic hermeneutics: the individualization of the first sentence of the sermon is continued ("everybody ... himself"); the listener is isolated and cast back upon him/herself; the question is aimed at the potential of humans; the figure of Nehemiah is presented as an example and as the law to the individual, etc. Especially conspicuous are the adjectives, nouns and adverbs that are used to strengthen the imperative, namely "all the sincerity of his soul" and, further in the sermon, "most profound sincerity"; also "positive ... continue the building"; "faithfully labour and pray"; "make ... willing," etc.

This emphasis reveals that, in the preacher's opinion, the appeals, as such, are too weak: they must be strengthened and radicalized, must adopt puritan dimensions. A person - the individual - must act in the superlative, must (in a legalistic way) be changed into the image of a Christ. The emphasis represents a type of reversed kenosis: not Christ who gives up his equality to God (sicut esse Deus; Phil 2:6) and becomes flesh, but people who give up their equality to people and (want to) become God, who determine God's actions through their actions. 
This can be seen, for example, in the conclusion of the sermon:

"Those who open their hearts for the Spirit of God and accept the cross with courage, will be heroes and heroines to God. Through faith, we must say: 'The God of heaven will allow us to succeed, and we, his servants, will prepare and build."”

Not for nothing are those who fulfilled the list of imperatives that were stacked in the sermon called "heroes and heroines." This is their reward. But then they must first open their hearts for the Spirit and courageously accept the cross, and they must be able to recite the specified biblical text - all human actions. Those individuals, who qualify to be the "we" of the sermon, rob God of his freedom in this way. However, the irony is that God cannot be robbed of his freedom, nor can individuals qualify for the high demands (e.g. to "open their hearts for the Spirit").

Naturally, individuals are important. The Gospel is about persons, not only about masses. However, in the above-named individualization, the individual is taken from his/her bond with the congregation; it no longer is two or three plus Christ (Mt 18:20), but an individual plus his/her potential.

Thus, the myth does not stand only on its own (timeless) legs. It needs human legs, human potential to keep itself alive in time - that of individuals... and a nation. In fact, the majority of sermons, deal with more than individuals. They deal especially with the nation. While God exonerates, truly exonerates, the myth as an unreal image demands unreality, the unattainable: that the nation will save itself. The myth compels. It does not tolerate people who live by grace, out of God's reality. Instead, it calls to the fore inhuman people, people without shadows and sins. For this the "national history" and "national heroes" offer the example, the primeval image. A compelling imperative emanates from them to transmit the myth from generation to generation, with the result that evangelical paranesis degenerates into mythical patriotism.

The consequences of this are far-reaching. Per definition, the church is defined away. This is logical: people who are not able, who are not strong and do not have the mettle, are not in line with this mythical patriotism. People with empty hands 
must stand aside for people with strong hands. Because the myth closes its eyes to Christ, it also does not see such empty-handed and broken people. It is the (theo)logical consequence of the myth: those who deny Christ also deny the congregation. After all, the congregation is nothing but one of the ways of life of the present and real Christ (Bonnhoefer, Christus als Gemeinde existierend; cf. Beckmann 1961:327-338). Other than his presence in, and as, the Word and Sacrament, Christ after all is also Christ pro nobis in, and as, the congregation insofar as the congregation is God's revelation, and insofar as his Word yearns for the image of a created body (Prenter 1965:262). By people living in theonomic reciprocity, i.e. through the grace of God as a congregation, each becomes a Christ for his or her neighbour (Luther). However, this actually takes place differently than in a legalistic anthropologization of Christology or the christologization of anthropology, as the basis for this is totally different: not in human beings, but in the Gospel. Therefore, the myth blinds itself also to the reality of the congregation, a reality born from the Gospel, and it supplies a surrogate: the "nation." The myth replaces God. The nation replaces the church. God is robbed on all sides: He has neither angels, nor a church....

That the boundaries between "nation" and "church" are flexible, that they are even alternative terms, is a fixed and - as far as the myth is concerned - a logical element in all the sermons. The church is swallowed up by the nation, and the nation is swallowed up by the church.

Out of an abundance of examples, only one:

"The powerful streams of alien ideologies surge against our nation and our church. Many of our fellowmen in faith are turning their backs on their church and nation, and on our own nation's past. Some of the leaders and quiet forefront fighters for alien influences in South Africa are people with Afrikaner surnames! Agitators against our church often have names of Dutch Protestants and Huguenots. Some so-called members of the church, whose names are still on the church's registers, use their power in movements that oppose the church and are alien to the nation!" 
The stereotypical "our nation and our church" (mostly also in this sequence) contain a conjunction ("and"), but, in fact, it functions as a unit and indeed as a threatened unit. Brothers in faith are equal to compatriots; those alien to the nation are simultaneously alien to the Gospel and "hostile to the church." Those who threaten the nation, threaten the church; those who become disloyal to the nation, become disloyal to the church. Nation and church shift seamlessly into each other. The fundamental rule is: God is pro nobis, if we are pro patria, otherwise not.

The interweaving of nation and church means the end of the fourth article of the confession of faith, the transformation of faith in the church into faith in a nation. The source of the church is no longer Christ, but the nation. An ecclesiological degradation takes place: the church figures virtually nowhere as a creation of God's Word (creatura verbi), but rather as a creation of either the individual, or the nation, as a self-generated product (creatura ipsissima). This perverted creational act depends on the assumption that the church is non-existent, or at least at the zero point. By means of fulfilling legalistic demands, a caricature of the church must thus be created, and it must be moved from nothing (ex nihilo) to the maximum national potential.

In this way, the church as una sancta catholica is fundamentally not understood nor appreciated. After all, in the myth the church is rooted in the national association itself and so separated from the ecumene. It appears that legalistic preaching, in general, results in a church being torn apart, and that a church being torn apart produces legalistic preaching (Bohren 1992:13). After all, the nation's faith is exclusive and therefore a schismatic faith: only those who are part of the national history, therefore of the nation, participate in it. Essentially, the sermons are not concerned about the one, catholic church, but about the condition of the nation. All the sermons include a type of "national programme" which consists basically of moralizing appeals. The nation must be strong and healthy. In this way, God will ensure its future. Within this national imperative framework, the unique nature of the church, as church of Jesus Christ, can in essence not come to fruition.

By this I do not deny that a close link between church and nation can exist. After all, the church is sent to all the nations with the command to make disciples of 
the people (Mt 28:19). However, this implies that the church must remain free from the nation, from all nations, exactly to be able to make disciples from their ranks. In that the theological sequence of church and nation is being reversed in the sermons, the nation usurps the position of the church and makes it powerless.

In his classic work on church and nation in German Missiology, Hoekendijk indicates that panta ta ethne is a terminus technicus for the whole of humankind out of whose midst God gathers his people. Therefore, the idea of national christianization has no foundation in the terminology of the mission assignment. Especially in the Old Testament, there is a much greater social differentiation than a mere schematization in national ordination. There is no mention of a "scriptural sociology" of national christianization. Furthermore, Israel is not the first historical example of an ideal nation, a primeval type for all other national concepts; that would mean secularization of the Old Testament's concept of God's people. God's people (church) and nation are not co-existent; there is a continuous "contrast of 'church' and 'nation"' (Hoekendijk 1948:235). Ethnic, linguistic and national moments of Israel are indeed mentioned and appreciated, but never form the basis of the nation. They are only peripheral phenomena of the novum: the people of God. God's people have no analogies, and cannot be fitted anywhere into existing formations. Sociologically, this is impossible (1948:229-237).

In this light, I want to expand on what Landau (1981:191) calls the anthroponomous subordination of God: when individuals do take the place of the Gospel not only as individuals, but as a group with a structured way of life and shared experiences, symbols, heroes, traditions and values, then it becomes a partitionomous subordination of God (partitiones = group). Then the group's descriptive norms and prescriptive laws rule over those of God, then their own values and appeals are sanctioned and mystified as though they are from God. God Himself is held captive intra muros mythi (within the myth's walls). He has to serve its establishment, maintenance, propagation and defence. Everything and all who oppose this, who do not think, act, speak and live accordingly, are regarded as enemies. (More about this in Chapter 4.)

The anthroponomous and partitionomous subordination of Christ does not imply that the Name of Christ does not appear formally in the sermons. In fact, a 
flood of Christological sentences that must conceal, rhetorically, more profound theological deficiencies often characterize legalistic sermons. After his analysis of a large number of legalistic sermons, Josuttis concludes that a false objectivity often appears in the Christology of these sermons. The Christological formulae that are handled are theoretically correct on the whole, but abstract, interchangeable in respect of the biblical text. Such Christological core sentences are often surrounded by a number of biblical sayings or hymnal verses, because, in this way, the preacher wants to disguise his principal inability to express biblical, Christological confessions as the Gospel for concrete people in concrete situations. A mist of secrecy, of inconceivability, of mythological admiration must then cover the Gospel. This process has a legalistic influence on the listener. The Gospel is not articulated as an offer of salvation, but rather presented as a holy example that must be reproduced. The Christ-event becomes a medium for the homo religiosus to complement his or her shortcomings; Christ becomes a Preceptor and Example for faith preservation (Josuttis 1966:61-70).

Where the Name of Christ indeed appears, it is mostly as an addendum, as a space-filler, possibly because the preachers subconsciously feel that the legalistic structure of their sermons cannot lead anywhere, cannot lead to life. Using the Name of Christ must negate the embarrassment with the unreality, must help to fill the theological gap in the proclamation. This procedure results in Christ not being presented as the Saviour, but as a national helper, and so Christology becomes idolized. Christ must help the nation on its way, and is presented as the great triumphant Example, as a superb "Mister Jesus" - who has never existed (Van Ruler 1969: 68). In reality, Christology thus serves the ideology of national justification.

For example, as follows:

"How serious the threat is - also for us in South Africa where we experience the same danger as Israel! We shall also cease to exist as an independent, pure Christian people, if we disregard the boundaries that the Creator has instituted. Should we not see much clearer the danger that threatens us as well as our descendents?" 
"There is only one Leader who can lead us and our descendents on a road that leads to security, safety and true independence - Jesus Christ. While holding our children's hands, let us faithfully seek Christ through his Word and through his church. Only then will our nation remain a Christian and happy people."

In these declarations, Christology is not only subject to the nation's "Christianity," but also its independence, safety, security and purity. Jesus is presented as the great Precursor, the "Leader" in this. On the one hand, the search for the Leader is the only way ("Only then ..."), in which the nation will remain Christian and happy. On the other hand, and contradictorily, the people will "cease to exist ... if we disregard the boundaries that the Creator instituted". Apparently Christ is not the only way to national security, but this can also be achieved by the people isolating themselves from other nations. Any possibility that Christ can hinder the nation on its way to purity and security is excluded. He must rather guarantee this.

In these sermons we have this sad contradiction: mentioning the Name of Christ is actually superfluous, but also not superfluous. It could also be interpreted as a concealed and subconscious cry for help, out of desperation and self-isolation. In this case, not only the law, but also legalism is a type of "disciplinarian," in a distorted way, to Christ (cf. Gal 3:24). This is an observation made by the Ecumenical Association in many analyses of legalistic sermons. The Name of Christ is taken into the service of humans, and at the same time expresses their deepest need of liberation, of the Gospel! However, in these sermons this distress call, in my opinion, comes too late. Up to the points when the distress call is heard, the sermons depend on a structure that profoundly affects the reality of the gospel. Luther called the negation of this reality nothing but an annihilatio $D e i$, an obliteration of God. This need not be expressed in crass atheism, but can also adopt refined forms, even in small, insignificant twists of language. Also here God can be made to conform to people's needs, can be recreated into a human image, when He (must) think like people, (must) want what they want (cf. Burger 1983:104-105). 
The annihilation of God, the displacement and replacement of God by images (cf. Chapter 2) can begin unobtrusively, also in Christology. However, those who damage a mere jot or title of the cross, obliterate it. The cross is not an addendum, but the heartbeat of the Gospel. Those who view the cross as an addendum to human potential leave no space for God's grace. After all, preaching, in fact, is a nihil nisi Christus praedicandus, a proclamation of Christ, of grace alone. In my opinion, these sermons exclude, methodologically and syntactically, the Gospel as a gospel of the cross. Speaking in respect of human logic, the foundational structure of these sermons cannot lead to the Gospel. After all, they do not need the Gospel. The myth has become its own gospel. And annihilated God. 


\section{THE THIRD HERMENEUTICAL STEP: OUTWARDS, WITH THE PROJECTION OF GUILT}

The analogical schematism forms an unreal image of history and appeals to people as unreal (i.e. innocent) people to maintain this image. One of the ways in which these people are raised and kept thus is by projecting their guilt onto others. The first step was a step back into, and out of, history, into the timelessness of myth. The second was a step inward, into the potential of the national soul. Now, the third is a step outward, projecting the guilt from the "inner group" (the nation) onto the "external group" (the enemies). Croatto's (1983:32ff) analysis of the Atrahasis epic indicates that the latter, in fact, is a centuries-old component of national myths. Such myths are implicitly against any form of revolution and, therefore, identify the guilty as targets as soon as the nation experiences uncertainty. Its own innocence must continuously be perpetuated with this projection of guilt. In the case of these sermons, it is this nation, after all, that must make the analogical schematism true, and so allow the myth to function. In a certain sense, this projection of guilt is the tip of the iceberg. Here, the deeper nature of the myth is apparent at its clearest, manifesting itself through the superficial structure of the (sermon) text, and confirms the preceding analyses in a concentrated way.

On the one hand, the homo intactus is thus regarded as a vital, active person. On the other hand, when it comes to complicity in what is wrong in history, homo intactus is regarded as a passive, sold-out person. Throughout, the enemy is regarded as the active force, but then in the negative, guilty sense of the word. This active-passive dualism forms a fixed component in each "situation analysis" 
that is made: the future existence and identity of the nation are at risk, it experiences one of its greatest crises - but did not cause it.

Two short examples: the first deals with Jeremiah 3:23 and illustrates the contrast of passive sufferers and active enemies.

The Afrikaner nation, indeed, finds itself in an unenviable position. We are eminently the target of hate-propaganda in virtually all countries worldwide. Many associations or complicities are busy inciting hatred and intolerance against us, apparently supported by virtually inexhaustible financial sources. In writings, newspapers, over the radio, by means of television, the crudest lies are exuberantly blazoned forth presenting our nation as evildoers.

"The plan is clear. We must be isolated and then ultimately be liquidated...."

"As regards weaponry, we may not receive the most essential for the protection of our own country and lives - we must be disarmed to eventually, with the least trouble, be dragged like sheep to the slaughterhouse."

"And what our condition will be on that day when the dark wave is allowed to break over us in its hellish power, what will happen to us, our wives, daughters and little children - one's heart wavers to even make a slight attempt to visualize this. Truly, death, a speedy death, may then be a preferable deed of grace!"

The activity of the "others" is described - their fierce hatred, thorough organization, complicities, incitement to intolerance, crude lies, deeds of isolation, liquidation, etc. All this is a dark wave that explodes in hellish power over "us." In contrast, "we" are a target, divested of the most essentials, sheep that are led innocently to the slaughter. An offering.

This passivation of verbs, which has a typical ideological function and contributes to the blurring of the main agents in a grammatical construction (Kress \& Hodge 1979:72ff; cf. also Chapter 2), reveals its extreme implications with this idea of an 
offering. In his multi-disciplinary study on myths, Grabner-Haider (1989:127128) indicates that, indeed, one of the basic traits of the myth, on the one hand, is to view the group as an offering by expressing helplessness and weakness with the help of emotion-driven linguistic structures. On the other hand, it is to purify the group from feelings of guilt by presenting the opposition as inherently evil (heretics, witches, enemies of God, etc.). Throughout this, the motive is selfpreservation, but ironically enough, it serves the spiral of guilt and destruction: the more the enemy is damned and destroyed, the greater the guilt and, therefore, the need for guilt projection.

A similar example from a sermon based on the New Testament deals with the miracle of the storm that Jesus stilled (Mk 3:35-41). After an introductory sentence that poses the "remarkable similarity" between the events on the stormy waters during which the disciples "had to call out with fear" and the "crucial times in which we find ourselves as a nation," the preacher continues:


terrible threats and this has not yet ended. Racial riots, the advent of a threatening anti-Christian nationalism, secret winds of communist incitement and internal violence also made us aware of problems, so that all started speaking about the problem and want to call out: 'Master, don't you care?"'

The situation is analysed, but again so that the audience ("our nation") adopts a passive role. External factors "threaten" them and they are endangered by "terrible onslaughts." It comes to a head with: “...this has not yet ended.” For example, there is still the "rise" of dangerous powers, of "secret winds" of communism that (like the stormy winds on the sea) blow stronger and stronger. The worst is still to come. However, the origin of the "problem" is external to the "nation." 
All of this "our beloved land ... had to experience." It is a law, an inevitable condition - the "nation" is exposed to an external power - in which it "finds" itself. Like the disciples "had to" call out, so the "nation" also "had to" experience the threatening catastrophe. All this is illustrated within the framework of the storm, a natural event that excludes guilt and has originated externally to the "nation," and is falling upon them - a mighty power that threatens to annihilate and thus sink them to the bottom. According to the preacher, the origin of the "problem", including the "racial problems," "racial violence" and the "internal violence", lies here.

This polarization by means of speech forms and images implies that actually there are two addressees in the sermon: the congregation and the oppositional forces who are addressed indirectly. The congregation becomes the witness to the open protest against these opponents (cf. Richter-Böhne 1989:123). In the process, distance is created between the congregation and the indirect audience. By speaking with extreme restraint about their own implication in the "problem" and with extreme expressivity about the implication of the other, a hostile image is outlined to the congregation. There can be no community, no unity between those who are near and those who are far. The first function of this projection of guilt is self-justification, in the sense that a negative delimitation of the others confirms their own identity. To the extent that the others are stigmatized as enemies of God, the nation is stabilized as friends of God; the polemic against the others strengthens the apology for what is their own. ${ }^{25}$

A sermon on Esther 4:14 illustrates poignantly how the polemic in this polarization is implemented. The point of departure is that there is a similarity between the time of Esther and "a time such as this." The preacher declares:

\footnotetext{
${ }^{25}$ The investigation of current preaching within this perspective would be an interesting study. In my opinion, there is reason to believe that this is still the case in some instances and that we work with a closed ecclesiology that needs an enemy to function. In this sense, the enemy not only threatens, but also confirms. Over the years, the Gospel has become "anti-something": anti-humanist; anticommunist; anti-gambling; anti-homosexuality, etc. Consequently, God exists by the grace of Satan and so evil becomes an essential element of the preaching. This is much more Zoroastrianism than Christianity!
} 
"Those who can discern the signs of the times correctly, will agree: we, the Afrikaner nation and Christendom in Southern Africa experience times of crisis as never before. About this, experts of our time agree ...."

"Our greatest danger is not the Communist force of arms or the military power of some or other country; our greatest threat is not a struggle against flesh and blood, but against the subtle power of the dark, that is unobtrusively and slowly but surely breaking down our nation and our Christian believers' spiritual standards, our sense of moral and spiritual values. Modern Hamans threaten our future existence. All around us we again hear the cry of the French Revolution: equality, liberation and brotherhood and a misplaced emphasis is placed on unity - often to the detriment of the natural differences between races, nations and churches, as willed by God; and a false ecumenicity is striven towards, to the detriment of pluriformity or variety. All over, we also observe the signs of a socalled dialogue between Protestantism and Roman Catholicism the truth and the lie. The slogan of the day is: away with differences - one church, one world, and one nation! And behind this slogan we see the Sovereign of the Dark who is preparing the world's scene for the appearance of the Antichrist. May God open our eyes before it is for ever too late. We are in a crisis!

Not only are there again the stereotypical "threats" from outside and "around us," but "our nation and our Christian believers" have spiritual "standards" and a "sense of moral and spiritual values" as an assumed capacity, and "we" are also able to "notice" and "observe" that the actual enemy of the "nation" is the "subtle power of the dark," the "Sovereign of the Dark." All this takes place against an apocalyptic background in which the "Antichrist" is coming. Here the polemic leads to the enemy being understood in terms of demonic activities. In a Manichaean and dualistic way, not only the world, but also God's relation to the world is divided into two: He is for "us," and He is against the "others" (cf. also Chapter 2 on God's dichotomy). In this sense, the situation analysis also serves 
the unreal; it grades the nation as superhuman, innocent people and it degrades the others as inhuman, demonic people! As a dichotomy of passive and active, of God's friends versus God's enemies, this depends on the fictitious alternative and hypothesis that the others are in the sphere of Evil, and the nation is in the sphere of Virtue. "We" are an offering because of "our" Christianity and devotion, and the "enemy" threatens because of its unchristian stance and Godlessness, because of its subservience to the "lie" and the "darkness." The intolerance of the myth is again evident in the nation's confronting the "others" (cf. Chapter 2).

Polemicizing and caricature of this kind opens the way, in turn, to take the nation's apology to its limit. The sermon on the history of Daniel and his three friends (also cited in Chapter 3) warns against the possibility that the world's opinion can eliminate the nation by the latter being equated with this opinion. A few conclusions read as follows:

"Now, we also know through history that there were always certain nations on earth who were a hindrance, and in the way of other nations. So, Israel was a hindrance to Babylon. Therefore, Israel had to be eliminated. This is also the case with our nation, who, with its particular view of God's will and way with us and God's destiny for us, today is an offence for many. The way in which we intend to exist, and also to exist in future, in our complex situation of race relations and problems that no other nation on earth has exactly like we have it, is simply not accepted - in fact it meets the anger and wrath of nations on the world's stage. There they feel that the world's spirit of citizenship cannot develop while there are 'stubborn' people in South Africa who want to remain members of their own nation as God created them. Therefore, eliminate them, is the slogan. Eliminate them by equating them with everybody. Teach them to speak the language of everybody else...."

"In our time, God seeks people who can say: 'My name is Christian; my food is God's will; and my language is my nation's language.' This small group of faithful people will experience what Daniel and 


\section{his friends experienced. Not human numbers, but God's wonderful} power will be decisive...."

Here, the apologia populi ("way in which we intend to exist and also to exist in future") is anchored in the predestination by God. When the preacher says: "So, Israel was a hindrance to Babylon... This is also the case with our nation, who, with its particular view of God's will and way with us and God's destiny for us, today is an offence for many," there is a direct and sanctioning line between "So ... was" and "So ... is". It implies: today the nation is what Israel was then, people whom God has sought, a "small group of faithful people" who cling to the truth against the rest of the world, against "nations on the universal stage." In this theological framework the others are not only conceived in terms of demonic activity, but the nation is also conceived in terms of God's predestining actions.

It is clear that this framework rests on a particular view of the doctrine of sin, a view in which the thought of concursus (co-operation) functions in a narrow and one-sided way. No distinction is made between transcendental and categorical causes in history, and people (in this case the nation) are ultimately portrayed as mere marionettes in the hands of the "Almighty." When guilt indeed is at issue, it is on account of the others. The nation's own sins, their involvement with the distorted course of history, are not mentioned at all in concreto and, in any case, dogmatically speaking, these sins are never conceived of as peccatum actuale. However, without this, no matter how "correctly" it is confessed before God, sin becomes abstract; as misunderstood peccatum originale, it becomes a docetic principle. After all, the one qualifies the other: on the one hand, a concrete deed is sinful because of its sinful origin; on the other hand, sin finds its outlet in people's concrete deeds to others. Sin always assumes an interhuman form; offences against God always include, as flip-side of the coin, offences against people. Sin is a religious, and therefore social, phenomenon (Berkouwer 1960:15ff).

In the light of the South African reality(!), the sermons serve to keep the nation free from guilt; as a matter of fact, they represent a carefully structured call not to repent. Actually, this cannot be any different: after all, the nation must carry the "promise" of the myth and dare not, as such, have any guilt. To proclaim or confess guilt is to play into the enemy's hands. In this sense, the nation rises even 
above Israel, above the fact that Israel's history is mainly one of unfaithfulness. Also, in this respect, the example of the forefathers is a decisive driving force. Note the pivotal role that the forefathers play in the following:

"Our ancestors experienced many crises. The Huguenots experienced a great crisis when the Edict of Nantes was recalled and they had to flee for their lives from their fatherland, France. But, they fled with the French Bible to the Southern-most tip of Africa."

"The Voortrekkers faced a huge crisis at Blood River; but, with the Bible in his hand, Sarel Cilliers could make a vow to the Almighty on their behalf."

"How dark it must have been for the representatives of the Boer commandos in 1902 at Vereeniging, when they had to sign away their country's independence! But, it was Rev. Kestell who took the men to a tent and there read Psalm 62 for them: 'My soul finds rest in God alone; my salvation comes from him.'

"In their dark hours our ancestors had the Bible as their guide. Our Calvinist fathers were oriented to Scripture. In our times of crisis, we must cling to the Bible. The Bible is strong and strengthens. Our fathers lived from the Scriptures, and the Scriptures declare: God is King. He reigns. But, I am his responsible child, through Him I have been predestined, and to Him I am responsible. Those who make this principle the foundation of their lives and world perspective, rise above the worldly and the sinful. Therefore, ask about the 'ancient paths ... the good way' that the Bible indicates and walk in them."

The "ancient paths ... the good way" of the Bible text (Jer 6:16), on the one hand, become a fulfilled law (the ancient good paths that the forefathers walked) and, on the other hand, an unfulfilled law (the ancient good paths that the nation also must walk in their crises today). This legalistic foundation leads to the preacher saying: "Those who make this principle the foundation of his or her life and world 
perspective, rise above the world and the sinful." Apparently, the demand of the forefathers is inexorable: they demand unearthly and sinless followers, people who no longer can be counted as simul justus et peccator, but rise above it.

When indeed sin is discussed, it is either in general or within the context of certain national ideals. Sin is conceived as the decline of the nation, as their failure to submit to their national existence and identity. Sin means no longer serving the "God of the fathers." Sin is breaking the tradition. Sin is being disdainful of the myth.

Therefore, the appeal for conversion and penance is mostly an appeal to return to a general, civil morality (cf. Bohren 1983:347). Robert Carrol (1991:35ff) is of the opinion that, in its most profound essence, fundamentalism is a protection of middle-class values. According to him, it is this ideology that "directs" the exegesis and the hermeneutics. Anything that comes into conflict with these values is regarded as sin; anybody who returns to these values is regarded as repentant. The result is that, ultimately, middle-class values become the final judge, the norm for the correct interpretation of God's revealed will in the Bible (cf. also Deist 1990:133). In this sense, penance is conceived as otherwise pious people's own active involvement in rectifying their moral shortcomings. In this way, God must be placated to ensure the nation's future existence. The deeperlying faith behind this implies: the nation is better than others, because the nation is humbler and vice versa - because the nation is humbler, more obedient and conscientious than others are or were, God chose the nation. The implication of this is that God's sovereignty, also to judge, is limited.

A few sermons, indeed, link the threat to the nation with their own sin, and they even experience it as God's judgement. The sermon based on Psalm 62:5, to which I referred in Chapter 2, for example, expresses it thus:

"'Find rest, O my soul, in God alone.' This is the language of humiliation when the threats become serious and frightening. When the dark clouds gather, when downfall is imminent, it is human to panic and to doubt, to seek allies, or to make concessions. But, herein a nation's salvation does not lie. When these events take 
place, it is a time of humiliation for the people. Then, a nation must come to Christ with its doubt. It must become still before God.

"And our nation must become still before God. A third of our nation has actually left God. For many the Word becomes a closed book. In the House of the Father their places are empty. Parents do not keep their baptismal vows. In our cities many sons and daughters live who are lost, and we already deal with lost children of lost parents. And, with the prophet, we must weep over the breaking of our sons and our daughters.

"But the nation must deeply humiliate itself especially before God over its deedlessness. We silence our consciences by speaking of a silent majority. We must realise that all that a nation needs to break down is to remain silent when wrong things are propagated. God does not have mute children. Therefore, we must humiliate ourselves over our cowardly silence, our insensitive deedlessness, our cold carelessness. On the spiritual side, the desired new life is still lacking. In the field of art, decadence flourishes and people who maintain the norms of God's Word do not confront it. On the social area, drugs, liquor and moral decline threaten us. On the economic terrain, experts must complain about methods that predict a nation's downfall. On our roads, people die. God's judgements repeatedly fall on our fatherland.

"And we do not tremble before God.

"There is reason for us to humiliate ourselves, to become silent before God. We have sinned. We must return to the God of our fathers."

The preacher points out that humiliation must take place "when the threat becomes serious and frightening," etc. The threat becomes the reason for humiliation (cf. also, "Then a nation must..."). So an attempt is made to give the nation's situation a theological meaning. This construction of "when ... then" 
implies that humiliation is not necessary otherwise. The reason for the humiliation is made parallel to the phenomenon of national decline (cf. "And our nation must become silent before God"). On the one hand, it is thus the external threat and, on the other hand, the internal national decline that are experienced simultaneously as "God's judgement." Sin is confessed ("We have sinned"), but this is conceived solely as a decline in national traditions and national religion. Conversion is a "return to the God of our fathers."

This and similar sermons with their proclamation of God's judgement are exceptions that should be welcomed. After all, we need the judgement, because when God comes to us with his judgement, He simultaneously embraces us with his grace (Luther). Yet, it is clear that the idea of national unity and national totality still influences this proclamation fundamentally. The point of departure is still: in the past, the whole nation was with God and God was with the whole nation. That a part of the nation has left God is a greater crisis than the possibility that God has left the nation, or that He never was with the nation in the way in which the preacher believes. This proclamation of judgement is a national complaint about the condition of the nation rather than a proclamation of God's judgement over all people and, as such, a proclamation of the need of God's salvific grace for all people. In this national complaint there is still the idyllic notion that this nation is special and, therefore, must remain special - other than other nations. (For a parallel, cf. Richter-Böhne 1989:113).

Therefore, the penance could also be understood at a different level. In the 1960s, but especially the 1970s, with the increasing isolation of South Africa, as well as the Dutch Reformed Church, an apocalyptic mentality developed (cf. Chapter 3), in which the "righteous" group (small as it was) conceived of itself as the true people of God and viewed all "onslaughts" as Godly purification, which implies not guilt, but a test. "He who perseveres will be saved." Therefore, it is no longer necessary to speak about guilt, only about perseverance, because those who do not persevere become part of the people who are punished, become part of the enemy.

However, in the majority of sermons, the link between the threat and God's judgement is totally absent. In fact, they repudiate this link. The projection of guilt fulfils in this - as I interpret it - a second function: not only is it an act of self- 
justification, but it serves as an escape route out of God's judgement - flight away from it. Sin, thus also God's judgement, is left at the address of others. The nation is kept innocent and free of judgement. This is quite logical: because the doctrine of justification through grace is affected in its core (cf. Chapter 3), God is no longer proclaimed as the Coming Judge. In fact, any form of judgement over the nation, even only signs of it that could be interpreted as pointers towards the ultimate judgement in history, is suppressed. After all, the closed system of the myth cannot tolerate any external influences and may not be relativized, but itself must remain the norm for judgement. No critical distance may be allowed between God's judgement and the myth.

However, between justification, as understood in the biblical sense, and judgement there is an inseparable bond. Faith in justification, which is revealed in Christ, includes the expectation of the Coming Judge, of the judgement of the living and the dead. In this sense, justification is behind and ahead of us. The Gospel of Christ, the Crucified, simultaneously, is the Gospel of Christ, who is to come. Therefore, proclamation of judgement also belongs to the heart of the Gospel (Bohren 1974:251-254).

In the sermons God is not only taken out of history and his current presence and work replaced with the presence and work of a people intact, but He is also taken out of the future. The sermons are in essence uneschatological. Christ will no longer come. People come. People must ensure the future. People take over the judgement -of others.

This uneschatological character of the sermons finds its breeding-ground, inter alia, in its basic legalistic form. Because law and Gospel are not clearly distinguished, and the law is thus not proclaimed as God's law, the radical perversion of the national myth and the need for radical (eschatological) change cannot be proclaimed clearly. On the contrary, the correct distinction of law and Gospel teaches us about what we hope for when we wait for the end of the world; it teaches us to truly yearn for liberation. Proclamation that takes this distinction seriously creates contradictions that provide content to our cry for the liberation of all things. In this way, the cry in our hearts for liberation becomes stronger, and it originates here, in this distinction, in the first place (Iwand 1964:217). 
Although, according to the sermons, the nation's way of life is a reason for anxiety and complaint, its reparation and maintenance are left for the nation's own account. The appeal to the nation for execution of the national ideal is regarded as the last (that is: eschatological) word. The view that the biblical imperatives are founded not only in the indicative of the salvific history, but are also supported by God's salvific promises, is absent virtually throughout. Instead of the promissio Dei, the potentia populi rather applies.

Like the creation of images (cf. Chapter 2), this is also a typical human reaction in times of fear. ${ }^{26}$ As a psychological phenomenon, anxiety is not as evident as, for example, the articulation of threat in the sermons, and yet, without doubt, it plays a decisive role. In a certain sense, it can even be regarded as the heuristic principle, as the factor that opens the mouths of preachers and forces the nation to listen with new attention. This determines the sermons' foundational structure in the sense that everything possible is done to counteract anxiety. The one pole in the sermons is the detailed description of the threat; the other is the "solutions" that are presented. This takes place within the field of tension generated by the anxiety.

One of the characteristics of anxiety is that it can cause a variety of reactions. For example, in situations of anxiety, defensive responses can be built up to protect one's own existence. This can stretch from primitive reactions to nuanced mechanisms. A common phenomenon is that anxiety about guilt - or better: anxiety about the consequences of one's own guilt - is replaced by anxiety about the impact of something external and threatening (Schulte 1957:222). Anxiety about guilt becomes anxiety about fate. This applies not only to individual behavioural patterns, but also to society. Collective guilt is suppressed by finding a communal external cause for the very circumstances in which those who are involved and responsible or co-responsible find themselves. With the assistance of social behavioural patterns, guilt is worked away and removed from the system (Mitscherlich 1967:21ff). However, in this way, anxiety may be replaced, but it is not removed. It continues to exert an influence, no matter how strenuous the

\footnotetext{
${ }^{26}$ In this respect, I do not endorse the distinction that says that anxiety is without object, and that fear focuses on a specific object. In practice it is evident that this distinction is forced (cf. Schulte 1957:220).
} 
attempts to eliminate it. This is so because anxiety, most profoundly, is not created just through fear of others, but by looking at one's own face (Schulte 1957:222).

In the sermons, the anxiety - I am trying to interpret it theologically - derives from the demasking of one's own face, and thus from God's own judgement. As such, it rests on a misunderstanding of the Gospel. Because, when God, being numinous, reveals Himself as God pro nobis, then $\mathrm{He}$ is feared (revered). Also, in his proximity to us, He is a mysterium tremendum et fascinosum, the incomparable, living God (cf. Chapter 2). However, this fear is totally different to the anxiety we have been speaking about. In my opinion, the human anxiety, characteristic of the sermons, is a result of the lack of fear of God. God's love, after all, is revealed to us in this: He sent his only Son to the world so that we can attain life through Him. And where (this) love is, there is no fear (anxiety); perfect love drives out fear, because fear expects punishment, and those who still fear, do not have perfect love (1 Jh 4:9,18). True fear of God originates from and grows in the shadow of the One who came, and those shadows being cast by the coming One, and this is the right way in which one should preach about the present and coming One (Bohren 1974:262).

Admitted, superficially anxiety seems like a significant factor. For example, it can be a powerful social manipulator that can be applied to keep the masses in check or to induce them to move, especially if it deals with a primeval anxiety about extinction (Schulte 1957:221-225). Yet anxiety is dangerous, even more dangerous than hatred. Appeals made on the basis of anxiety bring about little true change, but rather create a sensitivity about new anxieties. Ethical action manipulated through anxiety does not last long. On the contrary, it forms a destructive cycle that is extremely difficult to break. The anxiety that should have been exorcised becomes intensified. The longer the anxiety is kept alive, the more active it becomes, and the more it dims the view on reality and the possibility of cooperating in the transformation of this reality. In this respect, anxiety is a faithful expression of the myth (cf. Chapter 2). Apparently it puts everything in operation to preserve life. And then loses it. 


\section{CHAPTER 5}

\section{CONCLUSION}

As mentioned in the introduction, and as became evident repeatedly in the analyses, the sermons echo and articulate the Afrikaner nation's experience of being threatened. There is a dramatic wrestling to preserve the existing traditions, to confirm and conserve the status quo. The preachers do everything possible to reach this comprehensive objective, with far-reaching consequences for the theological quality of the sermons. All the preachers suffer under a type of national theodicy and question God's presence and involvement with the nation in its hour of crisis, and they try to solve this question moralistically (by means of appeals to people based on their abilities), instead of theologically. God pro nobis becomes God in nobis, and indeed in an anthroponomic and partitionomic conception and determination of the latter. People, a nation, must do what only God can do. In this way, the nation's crisis, their asking about God, ends in legalism (cf. Landau 1991:17). The good intentions, i.e. the proclamation of justification by grace, become the proclamation of self-justification, or rather national justification.

The tendency to implement Reformed and biblical concepts generously is significant, but frequently separate these concepts from their original contexts, abstract them and use them as key words and slogans for the ideal of national stability and national identity. So, for example, the Gospel becomes a national law, a religiously enhanced appeal to preserve the tradition. Jesus is transformed into an applicable medium in the service of patriotic moralism. The national history is surrounded with a radiance of holiness and becomes salvific history. For all practical purposes, nation and church are identical. God Himself becomes the personification of an idea, a mechanism by which national viewpoints are projected on a metaphysical level. God becomes nationalized. His freedom to be God, to choose and to reject, to be merciful and to judge, is thus curtailed. A 
reduced number of God's "characteristics" are presented, for example, that $\mathrm{He}$ "determines the destinies of nations," or that $\mathrm{He}$ is the "Almighty," etc. Other characteristics, such as his righteousness and his wrath, are avoided because it is problematic to fit them into the basic motif. Because these fall away, any opposition to the national vision is exclusively understood as the work of others, of the enemy. In this way, typically in national preaching of this nature, a loss of reality takes place in the sense that one's own (sinful) reality, as it exists before God, is lost sight of (Pressel 1967:352; Marsch 1964:534).

Preaching itself is misunderstood as a medium to realise and deepen certain national ideals. In my opinion, the analyses convincingly indicate this: preaching here no longer functions as an alternative, critical and therefore liberating word of God in the nation's situation, but merely as a sanctioning and stabilizing word. The nation's myth(s) thus take over the preaching to such an extent that the inner group's convictions are confirmed and strengthened in their contrast to the external group. In this sense, these sermons are indeed a good reflected image of the society (cf. the Introduction); they form part of the public discourse that took place in this era in political, social, cultural and ecclesiastical debates. Apparently, these sermons, as speech events, are so embedded in the contemporary types of speech and content, and they are so determined by the (then) current social, economic and political clichés and rhetoric - in short, by the broader network of the social language of the day - that they are swallowed totally by them. In my opinion, the sermons do not escape the "sucking power" of certain national myths and did not succeed in having a renewing and transforming effect on society. On the contrary, the irony is this: the sermons want to unlock the Gospel for the situation; instead the Gospel is locked up in the situation.

For this we must have some understanding. After all, we all live within contextual frameworks, with unilateral perspectives and exclusive myths. It is extremely difficult, even impossible, to step out of these frameworks and make "objective" and "neutral" judgements of them. Therefore, it must be said here: at least, these preachers still wrestled with the Bible, at least still asked about "God" within their framework. Only people in whom the Spirit works do this. Therefore, the contemporary generation of preachers must be critical of them as preaching fathers: but because they are our brothers we also accept them thus.... 
As is so often the experience with texts of this nature, the analyses had a disillusioning effect on me. From time to time I despaired at the meaning and value of preaching as such. Could we ever break away from the isolation, from the hold of our myths? To this there is no easy answer. No recipe or "law" can guarantee this. Preaching remains a dangerous enterprise. However, we can at least be made aware of, and become sensitive to, the influences that have an effect on preaching. That is a beginning.

We can learn - because it is a training process - to lose our first naivety about the interpretative event, to realise the relativity of all our interpretations, not trusting the validity of an exclusive one. The first step is indeed a hermeneutic of suspicion! (Ricoeur). As all language is a power play in service of ideology, whether conserving or innovating, an ideological-critical sensitizing process will have to be initiated, with an understanding of realities such as reception aesthetics, of the fact that all interpretations of texts are co-constitutive of the "meaning" of the text.

Concepts such as "Word of God," "authority of Scripture," etc., must be placed within a critical and historical framework, so that they do not become "objects." After all, a preacher stands amidst the dynamic flow of the biblical text itself, a process that implies that the text and its meanings are continuously "created," and never simply "exist" (Brueggemann 1988:127). This process comprises the creative origin of the text and its reception by the preacher him-/herself, as well as by the congregation as audience of the sermon. This creative process is unavoidable; neither should one try to avoid it, because this is the way in which God's Word lives in our midst. Therefore, our premises must frequently be questioned: what agendas, what "vested interests" are being served here (Brueggemann 1988:129)? Whose "story" enjoys preference? All this demands a greater level-headedness in preaching, as Brueggemann concludes: "Anyone who imagines that he or she is a benign or innocent preacher of the text is engaged in self-deception. Preaching as interpretation is always a daring, dangerous act in which the interpreter, together with the receivers of the interpretation, is consuming a text and producing a world" (1988:131-132).

Therefore, one of the main tasks of homiletics is to change the innocent eye into a wide-awake eye, an eye that observes and investigates the shadowy depths of our 
mythological worlds, and simultaneously is aware of its own distortions and blind spots (cf. Troeger 1988:209). So, it makes us aware of the interaction of interpretations, of the "stories" that live around the text, but also contributes to confront society's current metaphors and to enrich them with the metaphors and stories of faith. This requires a hermeneutic at the interlevel between exegesis and social analysis, a hermeneutic that not only walks in the world and stories of the text, but also in the world and the stories of the concrete and specific social situation in which the congregation lives (cf. Müller 1992). Such a hermeneutic cannot function with a one-eyed glassy stare, but with imagination and fantasy (cf. Troeger 1988:211). After all, Scripture itself is an inexhaustible source of interpretative possibilities, the language of which is loaded with possibilities to break through the old patterns, the old stories and myths. In this respect, the hermeneutic of suspicion is not an objective in itself, but must lead and invite us to a journey of discovery, a journey in which the text helps us to discover new worlds, new dimensions, a journey full of wonderment, born out of a hermeneutic of suspicion that, simultaneously, is an enquiring hermeneutic, a hermeneutic full of fantasy.

But, what do the contours of such a hermeneutic look like? In the light of the analyses, one could, for example, briefly say:

That one must deal extremely carefully with salvific-historical analogies, especially when these analogies are implemented to justify historical or current situations, or to deify them (cf. Marsch 1964:533). The Gospel rather demythologizes reality, as the reality before God.

That the tendency to categorize people in exclusive compartments of "good" and "bad," or "predestined" and "evil," with the concomitant projection of guilt from oneself to others, must be discerned and replaced with the language of being associated with guilt. As for example, in the language of the dying son, Markel, in Dostoevsky's novel, The brothers Karamasov, when he says to his mother: "Before everyone, we are guilty in everything, and I more than everybody."

That the claim that I, or we, are in possession of the absolute truth must make room for a wider vision, openness to the multifacetedness of the truth. The self-appropriation of ontological authority and divine indisputability 
must not only cause hermeneutical alarm-bells to ring, but must be confronted and revealed in its true essence: as power-speech in the service of ideology.

$\sim$ That any relation of domination that is perpetuated by language must be brought to the light ideologically-critically, by especially noting the tendency of ideologies to conceal themselves so in language that one's own guilt remains hidden away. In short, the destructive and dehumanizing elements of myths must be distinguished timeously (cf. Adonis/Smit 1991:28-30 on the analysis conducted by Grabner-Haider).

But how? By returning to the Word with openness to its inexhaustible possibilities of interpretation. Yes. But saying that we must return to the Word alone is not enough. We often read the Word just to strengthen our convictions. This is our dilemma. The problem of the South African society during the apartheid era was indeed the fact that our great variety (ethnic, cultural, political, social) had degenerated into a sinful partitioning, also in the church. A pattern of separation was established. Churches and groups read and proclaimed Scripture from their own experience and perception of the South African reality, often from directly opposite world views, with conflicting interpretative frameworks, perspectives, collective "stories" and myths. This problem was aggravated by the fixed conviction of such churches and groups that they did not, or did not wish to, proclaim anything but Scripture. The tragedy was that people, with the same Bible in their hands, and with the same Name of God on their lips, attacked each other by hand and mouth; that people said, or in any case subconsciously believed, that God is "for us" and "against the others."

We recently celebrated our democracy's tenth anniversary. We have come a long way since the dark days of apartheid. But it would be naïve to think that the history and culture of separation have been eradicated fully from our society and churches. On the contrary, we must be continually liberated from this. In my opinion, such a liberation can indeed take place, and particularly within the space of the ecumene, of the church in the broadest sense of the word. After all, the church as una sancta catholica, is God's gift to us; it is not the fruit of our hard work and is not dependent on our potential. The church is not based in our "wealth," which, in reality, is poverty, but in the wealth of Christ. That is his body, 
the fullness (pleroma) of Him who fulfils everything in everybody (Eph 1:23). Within this community there are enriching and controlling powers active like nowhere else. Here, we can continue to hear other voices, the voices of our brothers and sisters, their suffering under, and interpretation of, reality, their despair and hope. Here our myths can be relativized, revealed as precisely what they are: human-made constructions for our own prosperity. Here, in the creative co-operation of many interpretative models, unilateral fixations and omnipotent fantasies can be brought to light. Where there are two or three, the anxiety about each other, and about one's own face, is already half-conquered! Truly, we need each other, more than what we think or would admit. After all, the word of Christ in the mouth of my brother and sister is worth more than the word of Christ in my heart! (Bonhoeffer).

Thus, what I plead for is a continual ecumenical hermeneutic. If the church in South Africa still wants to play a role in the pastoral guidance and social therapy of a wounded society on the road to transformation and healing, then its rhetoric must also be liberated from its cultic restrictiveness and mythical sectarianism, to render a contribution outside the small circle that it serves over and over. In my opinion, the study of preaching offers a helpful point of departure in this regard. It provides an insight into the origin and development of historical and contemporary religious myths, and offers a wide and, simultaneously, a comparable data basis. It can contribute to greater understanding of the present philosophy and actions of others, by examining and assessing their theological and homiletical background and formation. It can especially stimulate discourse on the task of the church and the role of proclamation in a time of transition. It can lead to a better understanding of the identity of one's own faith community and that of the broader church, so that it can indeed play a meaningful role in the social context in which the faith community breathes, i.e. also in terms of the myths, symbols, stories, cultural perspectives and symbolic universums within which the greater community lives (Müller 1992:4).

How must all of this take place in practice? Who can initiate such a mutual listening to the proclamation of the church? Who, in our society with its history of separation, has the necessary integrity for this? I do not know. In any case, it will probably be a difficult process, a process that will require much maturity 
from all. The monoculture of churches, which even now still penetrates into theological training and communal life, will have to be replaced with a new culture, a new spirit of unity and a search for unity, a spirit in which the "hostile imagination" will have to make room for a "communal imagination" (Troeger 1988:208-218). Because it is especially within the creative play of the ecumene that a hermeneutic of fantasy can grow, where we can learn and see concretely in the lives of our brothers and sisters that Scripture does not provide simple answers to our existential and socio-political questions - but an arsenal of possibilities (Deist 1991:379); that God's will is not locked up in the Bible, theology or in tradition, as in an archive of certainties, but that God's will, indeed, must be sought, namely in the community of believers with their divergent opinions. We need precisely an alternative to our opinion if we want to come closer to the truth (Deist 1991:379). After all, God reveals Himself in the so-called contradictions of history. "Certainties on what we must think of God in our own time, we do not have. We only have the contradictions of our history, the biblical map and ... each other. What the Bible ensures us of is that God is present among us and that we need the testimony of rich and poor, slave and free man, man and woman, Jew and Greek if we want to recognize Him in this maelstrom" (Deist 1991:380).

It demands from us a deeper awareness of our own vulnerability, greater humility, a more intense spirit of ecumenicity, and ... confession of guilt. Within the school of the ecumene, it is difficult to suffer from collective or selective amnesia! The one reminds the other of unknown and unconfessed guilt. Without the ecumenical corrective, our (lack of) memory of past guilt often is nothing but a group-fabricated system of lies. However, in the broader community of believers, the possibility exists to confess guilt honestly to each other and to pray for each other, so that healing of a disrupted society can take place (cf. Jas 5:16). Within the ecumene there is a greater chance for conversion, to see and experience the movement and course of the Spirit - towards the ends of the earth and time, and the coming of Christ.... 
Günter Bublitz tells ${ }^{27}$ how he cycled one morning to meditate on the text about which he would preach the following Sunday. After a few metres he discovered that he was having difficulty in pedalling, that his outing was less pleasant that he had anticipated. He started perspiring. All pious thoughts about the text disappeared from his mind. He could only concentrate on the road before him. However, when Bublitz turned back, the situation changed: he could ride with the wind! With the power of the wind behind him, peace and reflection returned ....

The Spirit works. He blows so in the una sancta catholica that we frequently are brought into movement - in the right direction. Not towards new myths that probably will be created by new anxieties in a changed society, not to struggle against the wind of new exhausting and destructive powers, but to direct us to the living God of the one holy and catholic church. In this church the Spirit works so through our prayers, community and confession that we are made aware of the Gospel's realities and promises. Here we learn: in spite of our myths, God always still is God; in spite of our images, He always is the Living; in spite of our resistance to Him, He always still is: God for us.

In a personal correspondence with Gerd Debus. 


\section{SELECTED BIBLIOGRAPHY}

ADONIS, JC/SMIT, DJ 1991. Myth versus myth. Conflicting myths in South African religious discourse on violence. Apologia Vol. 6 No. 2.

ARENDT, H 1972. Wahrheit und Lüge in der Politik. Zwei Essays. Munchen.

BARTHES, R 1964. Mythen des Alltags. Frankfurt.

BARTH., K 1971. Die Gemeindemässigkeit der Predigt. Darmstadt.

BECKMANN, KM 1961. "Christus als Gemeinde existierend."' Der Begriff der Kirchein

Dietrich Bonhoeffers 'Sanctorum Communio' in Blick auf die Okumene”. Ev Th 11

Jahrgang.

BERKOUWER, GC 1960. Dogmatische Studiën. De Zonde II. Wezen en verbreiding Der zonde. Kok/Kampen.

BeSIER, G/SAUTER, G (HG) 1985. Wie Christen ihre Schuld bekennen. Die Stuttgarter

Erklärung 1945. Göttingen.

BOHREN, R 1993. Einheit und Zerissenheit der Kirche - Macht und Ohnmachtihrer Predigt.

Ev Th 53 Jahrgang.

BOHREN, R 1991. Predigen zum Weitersagen. Prediger-ausbildung in Kirche und

Universität. Referat am 8.2.91 bei der Generalversammlung des Okumenischen

Vereins zur Forderung der Predigt e. V. Nr 9/10.

BOHREN, R 1989. Beim Wort genommen. Ev Th 49 Jahrgang.

BOHREN, R 1989. Schlaf der Kirche - Gottes Erwachen. Predigtforschung und Gemeinde. Ev

Th 49 Jahrgang.

BOHREN, R 1988. Das Ich in der Predigt. Konsequenzen für den Lektorendienst. DMW 41

Jahrgang.

BOHREN, R 1983. Der Aufruf zur Busse. Past Th 83.

BOHREN, R 1981. Vom Heiligen Geist. 5 Betrachtungen. Kaiser Verlag, München.

BOHREN, R 1979. Geist und Gericht. Arbeiten zur Praktischen Theologie. Neukirchen.

BOHREN, R 1974. Predigtlehre. München.

BOHREN, R 1971. Reformatorische und Neuprotestantische Definition der Predigt. Ev Th 31 Jahrgang.

BOHREN, R/JöRNS, KP 1989. Die Predigtanalyse als Weg zur Predigt. Tübingen. Francke

Verlag.

BOSHOFF, GJJ 1959. U volk is my volk. Voortrekkerpers Bpk. Johannesburg.

BrakelmanN, G (HG) 1979. Kirche im Krieg. Der deutsche Protestantismus am Beginn des

II Weltkriegs. München. 
BRUEGGEMANN, W 1988. The social nature of a Biblical text for preaching. Van Seters(Ed) 1988, 127-166.

BURGER, CW 1983. Die verhouding Wet-Evangelie as hermeneuties-homiletiese prinsipe by Hans-Joachim Iwand. Ongepubliseerde proefskrif Stellenbosch.

CANCIK, H 1970. Mythische und historische Wahrheit. Interpretationen zu Texten der hethitischen, biblischen und griechischen Historiographie. Stuttgarter Bibelstudien 48. Verlag Katholisches Bibelwerk Stuttgart.

CARROLL, R 1991. Wolf in the sheepfold. The Bible as a problem for Christianity. SPCK London.

CILLIERS, JH 1982. Soos woorde van God. Ontwerp van 'n preekanalitiese model. Proefskrif, Universiteit van Stellenbosch.

CILLIERS, JH 1992. Prediking as ekklesiale diskoers: 'n ontwerp. NGTT Deel 33 No 3.

CROATtO, JS ET. AL. 1983. The idols of death and the God of Life. A Theology. Orbis Books. DEGENAAR, J 1986. Art and the meaning of life. Department of Adult Education and Extramural studies, University of Cape Town.

DEIST, FE 1978. Ope vrae aan die diskoersanalise (NGTT 14/4, p 260-271).

DEIST, FE 1990. Notes on the context and hermeneutic of Afrikaner civil religion

(Missionalia Vol 18/1, p 124-139).

DEIST, FE 1991. Objektiewe Skrifuitleg? Kanttekeninge by Skrifuitleg in die Nederduitse

Gereformeerde Kerk 1930-1990 (Herv. Teol. Studies 47/2, p 367-385).

DEIST, FE 1993. Honderd en vyftig jaar Bybeluitleg in die Nederduitse Gereformeerde Kerk.

'n Wetenskapshistoriese studie. RGN.

DIECKMANN, W 1969. Sprache in der Politik. Einführung in die Pragmatik und Semantik der politischen Sprache. Heidelberg.

DURAND, JJF 1976. Die Lewende God. Pretoria, NG Kerkboekhandel.

FAYE, JP 1977. Theorie der Erzählung. Einführung in die "totalitären" Sprachen. Frankfurt. GRABNER-HAIDER, A 1989. Strukturen des Mythos. Theorie einer Lebenswelt. Frankfurt.

Verlag Peter Lang.

GRANE, L 1971. Erwägungen zur Ontologie Luthers (NZ Sys Th Rd 13).

GREIDANUS, S 1970. Sola Scriptura. Problems and Principles in Preaching Historical Tests.

Wedge Publishing Foundation. Toronto Canada.

GRESCHAT, M (HG) 1985. Im Zeichen der Schuld. 40 Jahre Stuttgarter Schuldbekenntnis.

Neukirchen.

HANSON, PD (ED) 1983. Visionaries and their Apocalypses. Issues in Religion and Theology

4. SPCK London.

HOEKENDIJK, JC 1948. Kerk en volk in de Duitse Zendingswetenskap. Kampert en Helm, Amsterdam.

HOPEWELL, JE 1987. Congregation stories and structures. SCM Press Ltd. 
IWAND, HJ 1988. Frieden mit dem Osten. Texte 1933-1959. Hg GC den Hertog. München.

Kaiser Verlag.

IWAND, HJ 1964. Gesetz und Evangelium (in Nachgelassene Werke 4 Hg Kreck). München. JONKER, WD 1976. Die Woord as Opdrag. Pretoria: NGK Boekhandel.

JÖRNS, KP 1984. Segen-und kein Fluch? Uberlegungen zur Einheit Gottes im Vorfeld der

Praktischen Theologie. B Th Z 1.

JOSUTTIS, M 1966. Gesetzlichkeit in der Predigt der Gegenwart. München.

JUNGEL, E 1974. Metaphorische Wahrheit. Erwägungen zur theologischen Relevanz der

Metaphor als beitrag zur Hermeneutik einer narrativen Theologie. Sonderheft Ev Th. München.

KEARNY, R 1986. Modern Movements in European Philosophy. Manchester University

Press.

KLAUS, G 1971. Sprache der Politik. Berlin.

KRESS, GR/HODGE, R 1979. Language as Ideology: London: Routledge and Kegan Paul.

KRESS, GR/HODGE, R 1988. Social Semiotics. Polity Press.

KÜMMEL, WG 1974. Theology of the New Testament. London. SCM Press.

LANDAU, R 1991. Kirche Rechtfertigen. Ein Versuch. Vortrag am 28.11.1991.

LANDAU, R 1981. "Komm, Heiliger Geist, du Tröster wert ..." Gestaltungen des Heiligen

Geistes. Ev Th 41 Jahrgang.

LANGE, E 1976. Predigen als Beruf. Stuttgart. Kreuz Verlag.

MARSCH, WD 1964. Politische Predigt zum Kriegsbeginn 1914/1915. Ev Th 14 Jahrgang.

MARTI, K 1976. Grenzverkehr. Stuttgart.

MISKOTTE, KH 1965. Als de goden zwijgen. Haarlem.

MITSCHERLICH, A UND M 1967. Die Unfähigkeit zu trauern. Grundlagen kollektiven

Verhaltens. München. Piper Verlag.

MÜLLER, BA 1992. Hermeneutiek op die intervlak tussen eksegese en sosiale analise. PRT

7/1.

MÜLLER, BA 1987. Tendense in Afrikaanse Godsdiens Programme. Stellenbosch.

MÜLLER, CFJ (RED) 1980. Vyfhonderd jaar Suid-Afrikaanse geskiedenis. Pretoria, Kaapstad,

Johannesburg. publisher?

NAUDE 1963. Mythus en pseudo-mythus in die Griekse en Romeinse geskiedskrywing.

Unisa-mededelings.

PIETERSE, HJC 1991. Gemeente en prediking. NGKB.

PRENTER, R 1965. Jesus Christus als Gemeinde existierend. Ein Beitrag zum Verständnis

Dietrich Bonhoeffers. LM 41.

PRESSEL, W 1967. Die Kriegspredigt 1914 - 1918 in der evangelischen Kirche Deutschlands.

Göttingen. 
RICHTER-BÖHNE, A 1989. Unbekannte Schuld. Politischer Predigt unter allierter Besatzung. Stuttgart. Calwer Verlag.

SCHUlTE,W 1957. Zur Psychologie der Angst. EvTh 17Jahrgang.

SLÖK, J 1960. Mythos und Mythologie. In RGG Band 4, 37-42. Tübingen.

SUNDERMEIER, T 1990. Kultur und Nationalismus im Rassenkonflikt Südafrikas (in Kultur und Konflikt Hg Assmann/Hardt). Suhrkamp.

THURNEYSEN, E 1978. In seinen Händen. Grabreden. Ein Trostbuch. Neukirchen.

THOMPSON, JB 1984. Studies in the Theory of Ideology. Polity Press.

TROEGER, TH 1988. The social power of myth as a key to preaching on social issues. Van Seters (Ed) 1988, 205-234.

VAN RULER, AA 1969. Ik geloof. De twaalf artikelen van het geloof in morgenwijdingen.

Nijkerk: Callenbach.

VAN SETERS, A (ED) 1988. Preaching as a social act. Theology and practice. Nashville: Parthenon Press.

WEINRICH, H 1970. Linguistik der Lüge. Kann Sprache die Gedanken verbergen? Heidelberg.

WOLFF, HW 1969. Jahwe und die Götter in der alttestamentlichen Prophetie. Ein Beitrag zur Frage nach der Wirklichkeit Gottes und der Wirklichkeit der Welt. Ev Th 39 Jahrgang. 
D reaching reveals, amongst other things, the state of the heart of the church - whether it be healthy or ailing. Sermons from the South African apartheid era, taken from the official mouthpiece of the Dutch Reformed Church (Die Kerkbode), as preached during the years 1960 to 1980 reveal a church sickened by an ideology that had a devastating effect on the country as a whole. In this book, these sermons are analyzed in depth, following a method of "close reading" that not only takes the linguistic detail of each sermon very seriously, but also the theological perspectives conveyed by these details. These analyses bring to light the way preachers made use of biblical texts to sanction national ideals, to create and perpetuate selective God-images, and to stabilize a certain identity during a time of crises. It is saddening and shocking to read and relive these sermons, even after 12 years of democracy in South Africa. But it must not be erased from our memory too quickly. The church cannot do without remembrance. It watches over the state of her heart.

Johan Cilliers has written more than 30 books, seven of which are in the academic field of practical theology - dealing, amongst other things, with issues such as homiletics and ethics; liturgy and aesthetics; and basic principles of preaching. He has ministered for 18 years in congregations in South Africa and currently is associate professor in Homiletics and Liturgy at the Faculty of Theology at Stellenbosch University in South Africa.

\section{ww w. africansunmedia.co.za}

